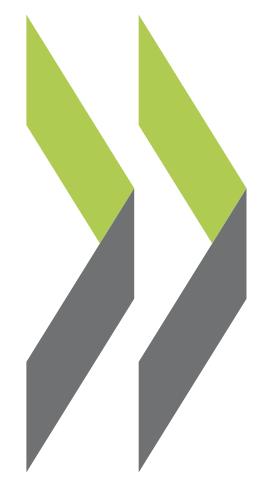

OECD Economics Department Working Papers No. 1444

Ensuring a dynamic skillstraining and life-long learning system Petar Vujanovic, in Switzerland 


\section{Unclassified}

ECO/WKP(2017)76

Organisation de Coopération et de Développement Économiques

Organisation for Economic Co-operation and Development

\section{ECONOMICS DEPARTMENT}

English - Or. English

\section{ENSURING A DYNAMIC SKILLS-TRAINING AND LIFE-LONG LEARNING SYSTEM IN SWITZERLAND}

ECONOMIC DEPARTMENT WORKING PAPER No. 1444

By Petar Vujanovic and Christine Lewis

OECD Working Papers should not be reported as representing the official views of the OECD or of its member countries. The opinions expressed and arguments employed are those of the author(s).

Authorised publication by Alvaro Pereira, Director, Country Studies Branch, Economics Department.

All Economics Department Working Papers are available at www.oecd.org/eco/workingpapers

This document, as well as any data and map included herein, are without prejudice to the status of or sovereignty over any territory, to the delimitation of international frontiers and boundaries and to the name of any territory, city or area. 
OECD Working Papers should not be reported as representing the official views of the OECD or of its member countries. The opinions expressed and arguments employed are those of the author(s).

Working Papers describe preliminary results or research in progress by the author(s) and are published to stimulate discussion on a broad range of issues on which the OECD works.

Comments on Working Papers are welcomed, and may be sent to OECD Economics Department, 2 rue André-Pascal, 75775 Paris Cedex 16, France, or by e-mail to eco.contact@oecd.org.

All Economics Department Working Papers are available at www.oecd.org/eco/workingpapers.

This document and any map included herein are without prejudice to the status of or sovereignty over any territory, to the delimitation of international frontiers and boundaries and to the name of any territory, city or area.

The statistical data for Israel are supplied by and under the responsibility of the relevant Israeli authorities. The use of such data by the OECD is without prejudice to the status of the Golan Heights, East Jerusalem and Israeli settlements in the West Bank under the terms of international law.

\section{(C) OECD (2017)}

You can copy, download or print OECD content for your own use, and you can include excerpts from OECD publications, databases and multimedia products in your own documents, presentations, blogs, websites and teaching materials, provided that suitable acknowledgment of OECD as source and copyright owner is given. All requests for commercial use and translation rights should be submitted to rights@oecd.org 


\section{ABSTRACT/RÉSUMÉ \\ Ensuring a dynamic skills-training and life-long learning system in Switzerland}

Switzerland makes more use of its human resources than most other OECD countries. Labour force participation is high and the unemployment rate low for most segments of society. This ensures a high standard of living for most Swiss people. Nevertheless, productivity growth is relatively slow. While this may in part be attributable to already being an advanced economy, it also means that Switzerland cannot be complacent with regard to education and skills. Its admirably low youth joblessness suggests that the transition from education to work is functioning soundly. However, there is mounting evidence that as the structure of industry is changing, due to globalisation and digitalisation for instance, vacancies and skills mismatches are spreading. The mix of skills being taught differs from those taught in most other high income OECD countries in which a common secondary school track predominates and the emphasis is on equipping young adults with academic tertiary qualifications. In this context, it is important that the system is flexible enough to respond to shifts in the demand for skills and that workers continue to learn. While the participation of women and immigrants in the economy compares relatively well, more can still be done to improve equity in the accumulation of skills.

This Working Paper relates to the 2017 OECD Economic Survey of Switzerland (http://www.oecd.org/eco/surveys/economic-survey-switzerland.htm).

JEL classification: I24; I25; I28; J24; J48

Keywords: Switzerland, skills, vocational education, training, labour market, lifelong learning.

\section{Assurance le dynamisme du système de formation professionnelle et de formation continue}

La Suisse mobilise davantage ses ressources humaines que la plupart des autres pays de l'OCDE. Le taux d'activité y est élevé et le taux de chômage faible dans la plupart des segments de la société. La plupart des Suisses bénéficient ainsi d'un niveau de vie élevé. Néanmoins, la croissance de la productivité est relativement lente. Bien que cela soit probablement en partie imputable au fait que la Suisse est déjà une économie avancée, cela signifie également qu'elle ne doit pas relâcher sa vigilance en ce qui concerne l'éducation et les compétences. Le niveau remarquablement bas du taux de chômage des jeunes montre que la transition de l'école au marché du travail fonctionne bien. Toutefois, un nombre croissant de données indiquent qu'à mesure que la structure de l'économie évolue, sous l'effet de la mondialisation et de la transformation numérique par exemple, les emplois vacants et les problèmes d'inadéquation des compétences se multiplient. L'éventail de compétences enseignées est différent de celui enseigné dans la plupart des autres pays de l'OCDE à haut revenu, dans lesquels prédomine une filière générale d'enseignement secondaire et qui s'efforcent de doter les jeunes adultes de diplômes universitaires. Dans ce contexte, il est essentiel que le système soit suffisamment souple pour s'adapter à l'évolution de la demande de compétences, et pour que les travailleurs continuent à se former. Bien que la participation des femmes et des immigrés à l'économie soit relativement satisfaisante par rapport à d'autres pays, il reste encore de la marge pour améliorer l'équité en termes d'accumulation de compétences.

Ce Document de travail se rapporte à l'Étude économique de l'OCDE de la Suisse 2017

(http://www.oecd.org/fr/economie/etude-economique-suisse.htm)

Classification JEL: I24; I25; I28; J24; J48

Mots clefs: Suisse, compétences, formation professionnelle, formation, marché du travail, formation continue. 


\section{TABLE OF CONTENTS}

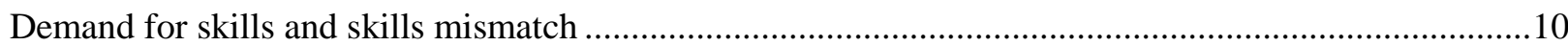

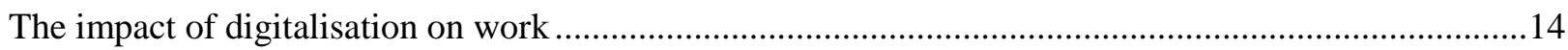

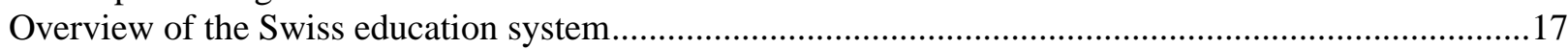

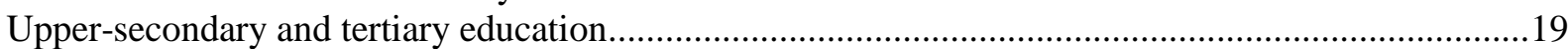

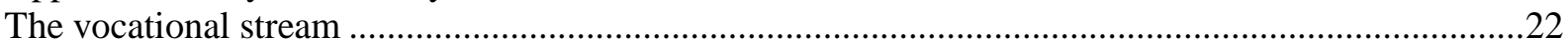

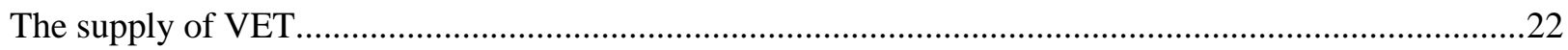

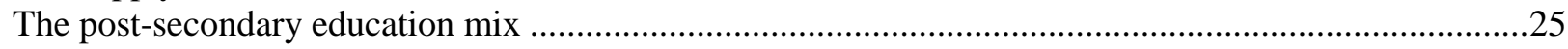

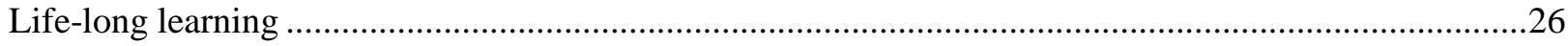

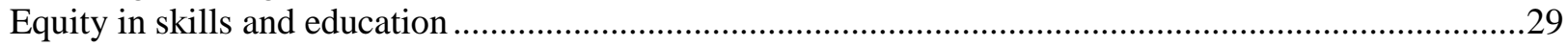

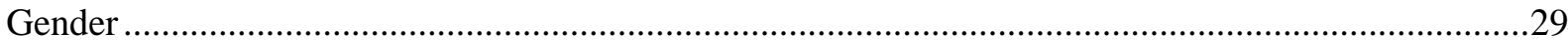

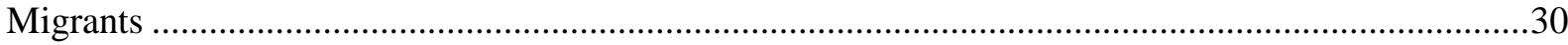

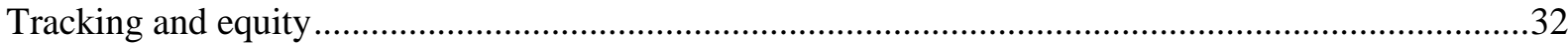

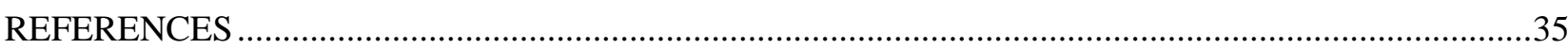

\section{Tables}

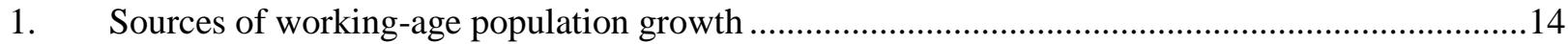

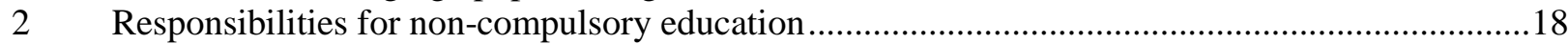

3. $\quad$ ISA scores and gender differences across selected countries ...................................................19

\section{Figures}

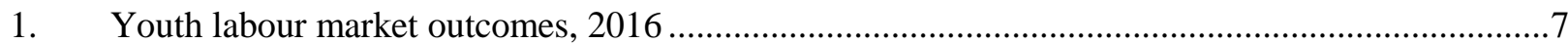

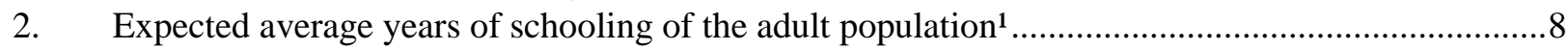

3. Public expenditure on educational institutions by level of education ............................................

4. Most of Switzerland's job growth has been in high-skill jobs .................................................10

5. Job vacancy rates by sector in Switzerland and in the ICT sector across Europe...........................11

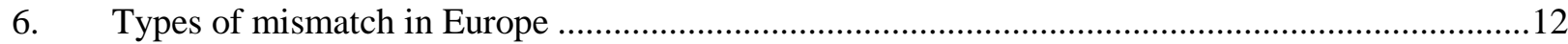

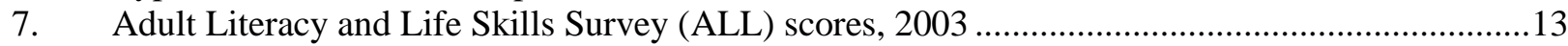

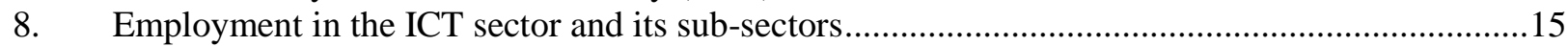

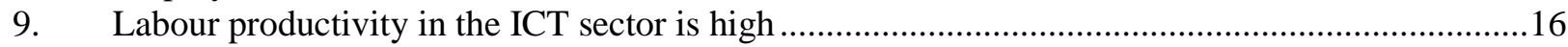

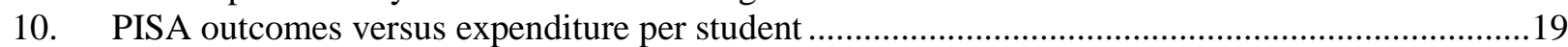

11. Percentage of 25-64 year-olds whose highest level of education is upper-secondary or post-

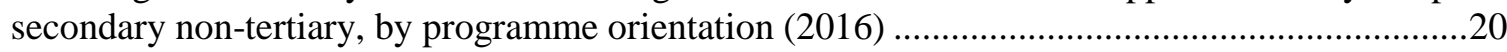

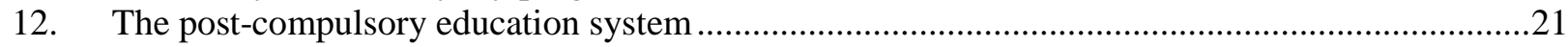

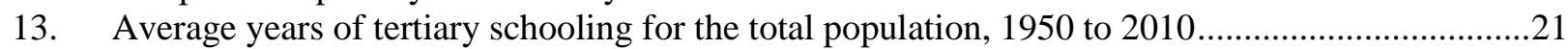

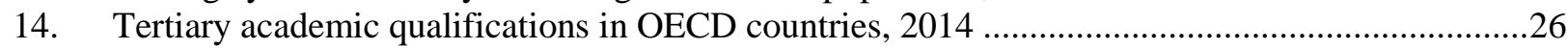

15. Participation in life-long learning across Europe by educational attainment...............................28

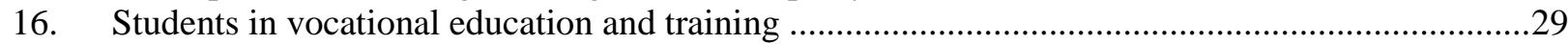

17. Difference in PISA science score levels between students in schools with high and low concentrations of students with an immigrant background, 2015 ... 
ECO/WKP(2017)76

\section{Boxes}

Box 1 Strengths of the Swiss vocational education and training system .................................................

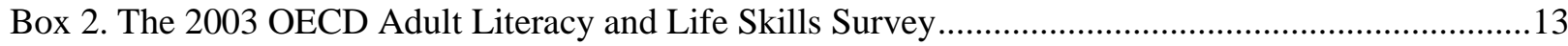

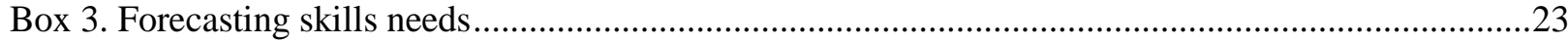

Recommendations to make education and skills training more responsive ...........................................34 


\title{
ENSURING A DYNAMIC SKILLS-TRAINING AND LIFE-LONG LEARNING SYSTEM
}

\author{
Petar Vujanovic and Christine Lewis ${ }^{1}$
}

The fundamental importance of education in economic and social development cannot be understated. Sustained long-term growth is underpinned by education. Without proper investment in skills, technological progress does not translate into economic growth, and countries can no longer compete in an increasingly knowledge-based global society (Hanushek and Wößmann, 2008 and 2011; Krueger and Lindahl, 2001). Moreover, cognitive skills directly affect individual earnings and the distribution of income. Not only are the income returns to education monotonically positive on average, but even more fundamentally, education helps people make informed economic and social choices and raises social engagement and health outcomes (OECD, 2010a; Campbell, 2006). Crucial and complex phenomena such as digitalisation, deindustrialisation and the future of work require skills policies that make societies more resilient to the changes that lie ahead - including skills upgrading and ensuring a better use and distribution of existing skills.

The accumulation of human capital boosts labour productivity, and more broadly it also feeds into multi-factor productivity by smoothing the interface between labour and capital. But the types of skills needed shift over time as the structure of the economy changes with the introduction of new technologies and evolving consumer tastes. Education systems need to be flexible enough to respond. One approach is to put heavy emphasis on providing students with foundation skills and the capacity to learn, thereby equipping them with a solid footing upon which subsequently specialised skills can be efficiently built, as needs arise. In this way, the workers themselves are adaptable throughout their working lives. The other approach is to have a system that promotes specialisation but is flexible enough to quickly adapt to changing labour market demands. Of course, a mix of these two approaches is also possible (OECD, 2012a). Skills should also be seen as a tool to be honed over an individual's lifetime. It is therefore important to take a strategic approach to assess the impact of different kinds of learning - from early childhood education through formal schooling to formal and informal adult education and training - with the aim of balancing the allocation of resources to optimise economic and social outcomes.

Switzerland's high living standards are partly attributable to its level of human capital, which compares very well to that of other OECD countries as measured by overall education participation and outcomes. The education system prepares young people commendably for the transition from education to work, with an enviably low youth unemployment rate (Figure 1, Panel A) and low numbers of youth not in employment, education or training (Panel B). Part of this success is due to the comprehensive and wellintegrated vocational education and training system, which does an excellent job of transitioning students of all abilities into the workforce (Hoeckel et al., 2009; OECD, 2009 and 2010b; Box 1).

1. Previously Head of the Switzerland desk in the OECD Economics Department and currently Head of the Switzerland desk, respectively. The authors would like to thank Peter Jarrett, Patrice Ollivaud, Mathilde Pak and Alvaro Pereira (from the Economics Department), Victoria Galan Muros, Malgorzata Kuczera, Liam Lynch, Gabriele Marconi, Shane Samuelson and Claudia Sarrico (from the Education Directorate) and Thomas Liebig and Glenda Quintini (from the Directorate for Employment, Labour and Social Affairs) for useful comments and suggestions. The paper has also benefitted from comments by Swiss officials and by members of the OECD Economic and Development Review Committee. Special thanks go to Anne Legendre and Klaus Pedersen for statistical assistance and Elisabetta Pilati for editorial assistance (all from the Economics Department). 
Figure 1. Youth labour market outcomes, 2016
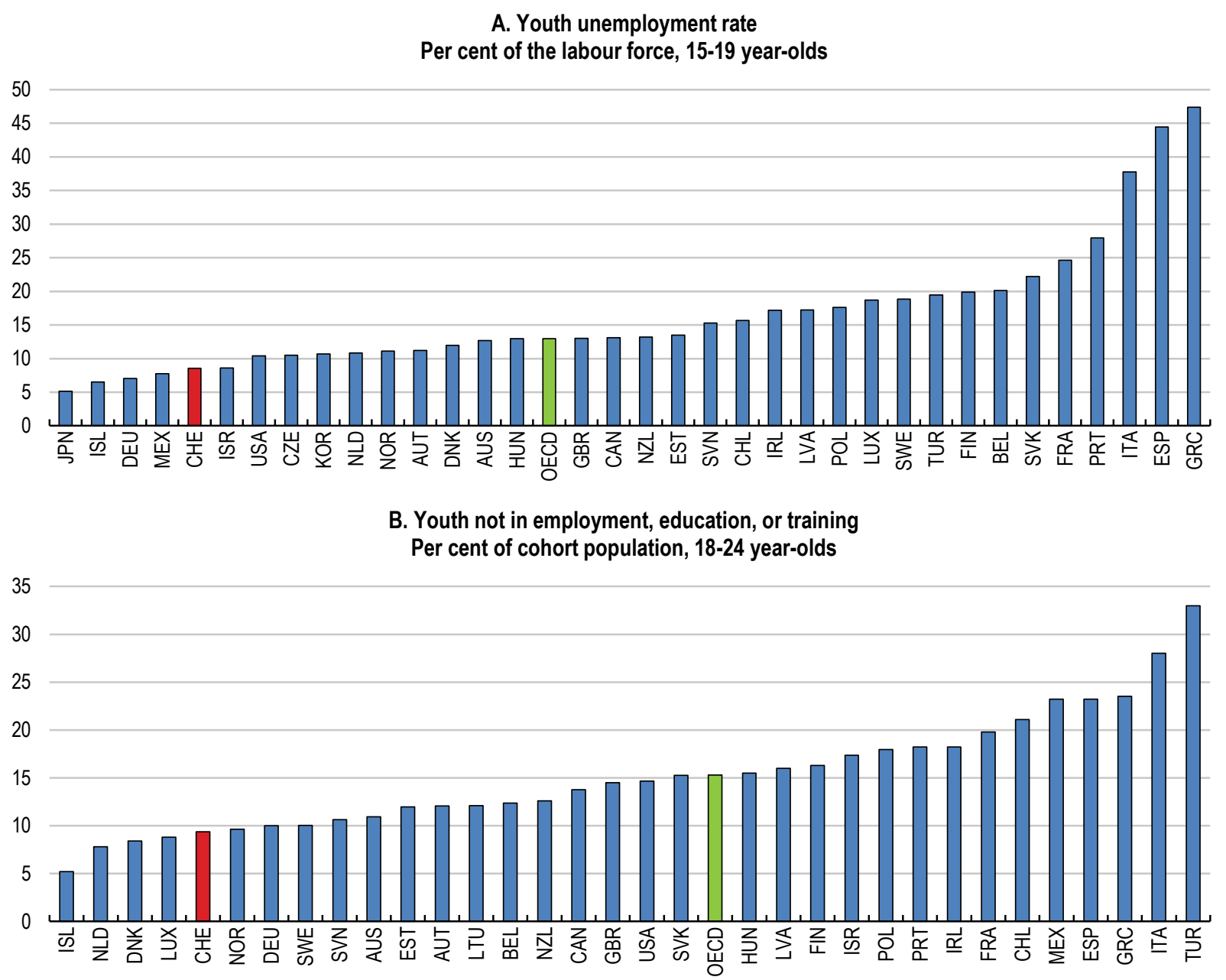

Source: OECD, Employment database; OECD (2017), Education at a Glance 2017.

\section{Box 1 Strengths of the Swiss vocational education and training system}

Earlier OECD studies of Switzerland's vocational education and training (VET) system highlighted a number of strengths of the system that contribute to its good labour market outcomes. These include:

- $\quad$ The system is strongly employer and market driven. Employers and professional associations are engaged with and actively contribute to education and training. The partnership between Confederation, cantons and professional organisations works well.

- School and work-based learning are well integrated and workplace training is not too company-specific.

- The tertiary VET system ("professional education and training") offers a wide range of progression opportunities for apprentices graduating from upper-secondary VET.

- $\quad$ There is a broad spectrum of tertiary VET offerings. The system offers a flexible and effective response to diverse student requirements, with part-time, evening, weekend and modular provision. Work-based learning is generally well integrated into tertiary VET programmes, with work linked to study for part-time students, and substantial internships for full-time students. 
- Teachers and trainers in professional colleges are well prepared both in their vocational field and in pedagogy.

- $\quad$ The professional exams in the tertiary VET system effectively link upskilling to recognition of prior learning.

Source: Fazekas, M. and S. Field (2013), A Skills beyond School Review of Switzerland, OECD Publishing, Paris. http://dx.doi.org/10.1787/9789264062665-en; Hoeckel, K., S. Field and W. Grubb (2009), Learning for Jobs: OECD Reviews of Vocational Education and Training: Switzerland, OECD Publishing, Paris, http://dx.doi.org/10.1787/9789264113985-en

Switzerland, like Germany, the Netherlands, Austria and the Scandinavian countries, is characterised by a high level of educational stratification, with a well-established track of vocational education and training both at secondary and tertiary levels. Around two-thirds of secondary students follow the vocational track, where courses of study are typically of shorter duration, and this in part explains Switzerland's average ranking in terms of years at school (Figure 2). While there was a rapid increase in the average years of schooling through the 1960s and 70s - the period during which the vocational education and training system including apprenticeships was formalised - this increase all but stopped until the late 2000s, while in many other OECD countries it continued.

Figure 2. Expected average years of schooling of the adult population 1

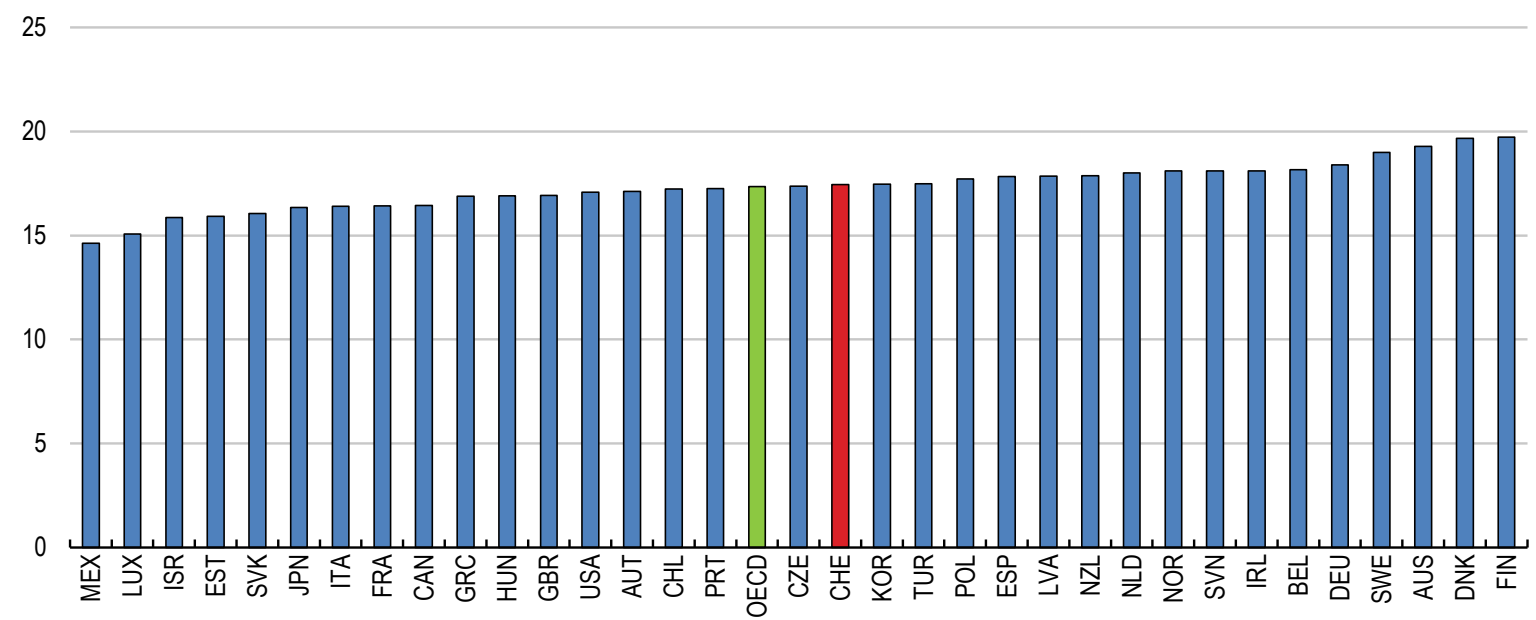

1. This indicator is the average duration of education in which a five year-old child can expect to enrol during his/her lifetime until the age of 39. It is calculated under the current enrolment conditions by adding the net enrolment rates for each single year of age from the age of five onwards.

Source: OECD (2016), Education at a Glance 2016.

The high level of stratification and relative complexity of the Swiss education system reflects the extensive organisational decentralisation, based on the principles of subsidiarity and direct democracy. Financing is also highly decentralised with $96 \%$ of public funds from sub-national government, even before transfers (OECD, 2017a). Pre-school, primary and lower secondary education are essentially under cantonal jurisdiction. Only in 2006 was the constitution modified to give the federal authorities the right to enact regulations concerning compulsory schooling under certain conditions. After compulsory schooling, responsibilities vary between the academic and vocational streams. Upper-secondary general (academic) education is managed largely at the cantonal level, while vocational education and training is the responsibility of the federal government. In tertiary education jurisdiction is cantonal for universities, regional for universities of applied sciences and federal for the Swiss Federal Institutes of Technology. There is, however, substantial coordination between all levels. The segmented structure of the education system means that students of all aptitudes and preferences are catered for and therefore remain in education after completing compulsory 
education, usually at age 15 . At the age of 18 around $83 \%$ of the population is still in some form of education (FSO, 2015). Switzerland also ranks highly in the proportion of people who have attained at least an uppersecondary school education (88\% of 25-64 year-olds; OECD, 2013 and 2017a).

Switzerland's public spending on educational institutions, from primary to tertiary, is close to the OECD average relative to GDP (Figure 3). In 2014 public spending was 14\% of government expenditure, above the OECD average of $11 \%$. Spending per student is high in PPP-adjusted terms (USD 17 436) relative to other OECD countries (where public and private average USD 10 759). As in other OECD countries, average spending per student is higher at tertiary educational institutions than the average of lower levels of education. Spending per tertiary student is outdistanced only by Luxembourg and the United States. However, Switzerland's high level of spending is driven by R\&D activities and the level of spending is closer to the average when these are excluded.

Figure 3. Public expenditure on educational institutions by level of education 1

Per cent of GDP, 2014

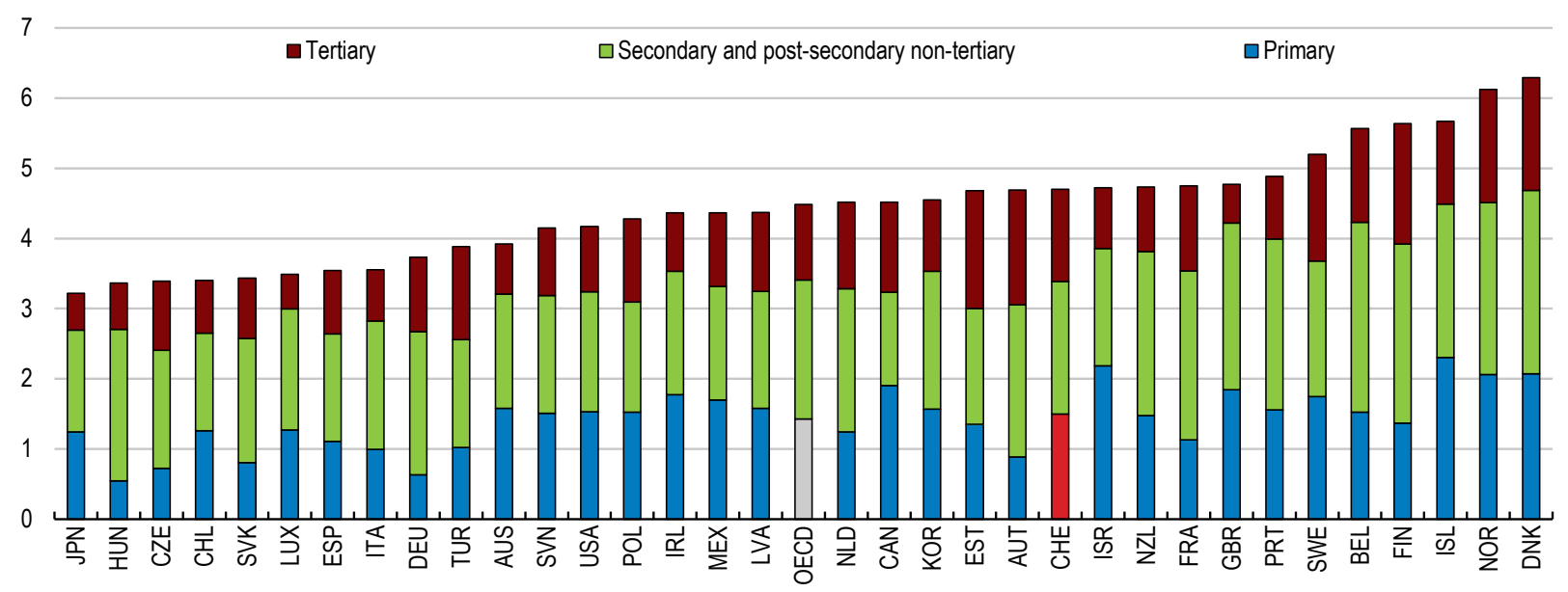

1. Including public subsidies to households attributable for educational institutions, and direct expenditure on educational institutions from international sources.

Source: OECD (2017), Education at a Glance 2017.

With regard to outcomes, in the 2015 PISA exercise Switzerland ranked third among OECD countries in the mathematics performance of 15 year-olds, 12th in science and 22nd in reading (OECD, 2016a). Indeed, in the 2015 iteration Switzerland is notable with regard to the dispersion of its rankings across subjects. Germany, for example, ranked 11th, 10th and 9th across subjects, and the Netherlands ranked 6th, 11 th and 12th. While student performance across Swiss linguistic regions is remarkably homogeneous, the very large number of students who speak a language other than that used at school (above the OECD average) may explain the weaker reading scores (OECD, 2016b).

Switzerland did not participate in the OECD Survey of Adult Skills (PIAAC) in 2016. This is unfortunate, as making up-to-date international comparisons of Switzerland's performance relative to other OECD countries would have been instructive, especially given skills shortages and the challenges posed by digitalisation and other far-reaching changes (see below). Moreover, the virtual absence of longitudinal or cohort data within the Swiss education system makes in-depth analysis difficult (SKBF, 2014). This lack of data makes it hard to assess the effect of the current education arrangements on equity and labour market and other outcomes. The creation of student identifiers in educational statistics will bring about an improvement in this respect over the long term, as it will allow better individual tracking in the statistics. 
The 2015 OECD Economic Survey of Switzerland made several recommendations as to how Switzerland could make its education system more inclusive and responsive to labour market needs (OECD, 2015a). One of the main recommendations was to raise enrolment in early childhood education and care, which would increase the overall effectiveness of the system, especially for underprivileged students, including migrants. This issue is taken up in further depth in this paper, especially regarding the effect on equity of the education system, which splits students into vocational and academic streams as well as classes based on ability.

\section{Demand for skills and skills mismatch}

One of the principle objectives of every education system is to prepare young people for the workforce by providing them with the knowledge and skills that match those in demand in the jobs market. Without sufficient investment in skills, people languish on the margins of society, technological progress does not translate into economic growth, and countries can no longer compete in an increasingly knowledge-based global society (OECD, 2016a). In addition, for skills to retain their value they must be maintained and upgraded throughout life. Matching the skills taught with job-market demands is a challenge that countries increasingly have to face as technological change accelerates.

Over the past decade and a half Switzerland has enjoyed comparatively strong employment growth, averaging $1.1 \%$ per year. As in most other European countries, most of this growth has been in the highskilled occupations (Figure 4), while low-skilled jobs have grown more moderately, and the number of middle-skilled jobs has retreated. The demand for labour has clearly been tilted toward high-skilled workers and away from their middle-skilled counterparts.

Figure 4. Most of Switzerland's job growth has been in high-skill jobs'

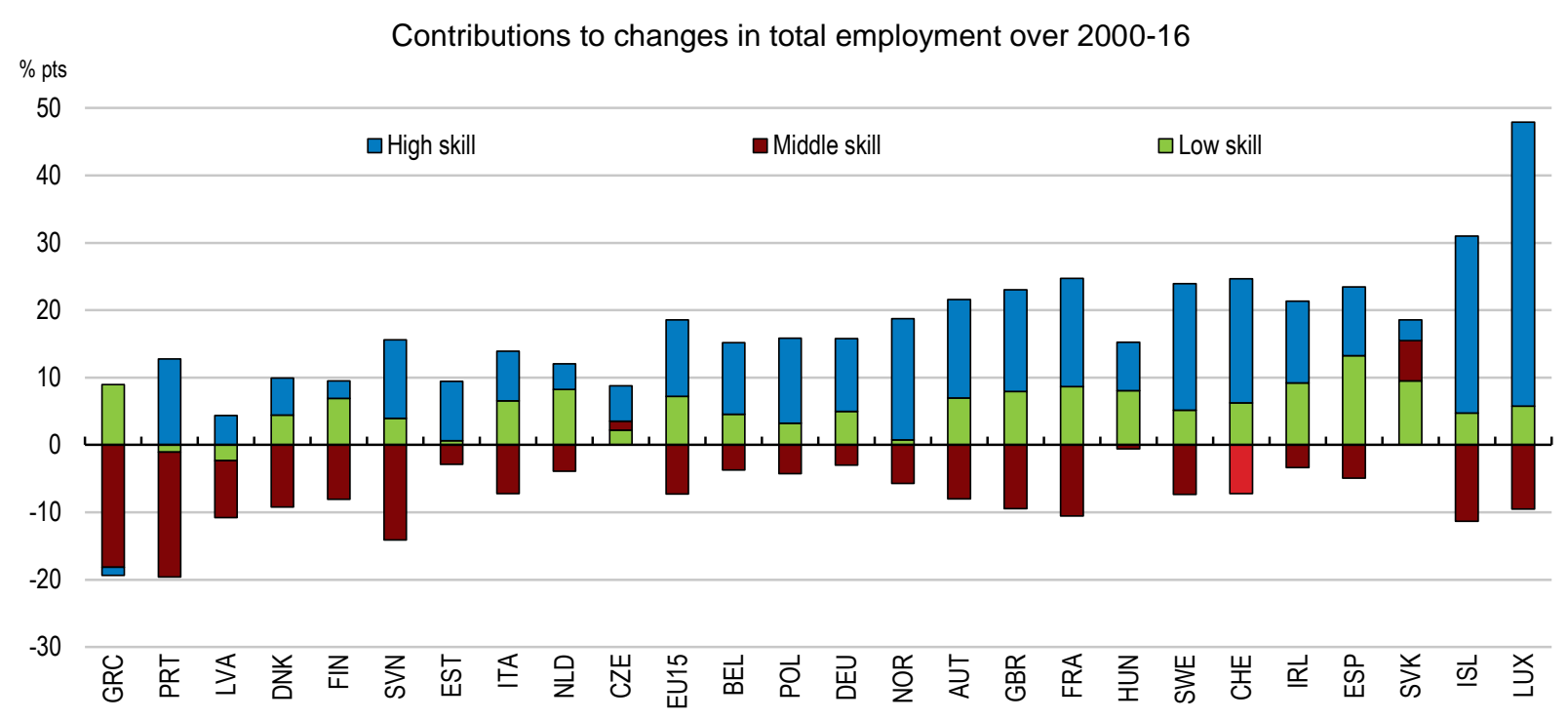

1. Countries are ordered by the change in net employment over 2000-16. High-skill occupations are: managers, professionals, and technicians and associate professionals; medium-skill occupations are clerical support workers, skilled agricultural workers, craft and related trades workers and plant and machine operators and assemblers. Low-skill occupations are service and sales workers, and elementary occupations. The armed forces and non-responses are not shown.

Source: Eurostat.

While overall both the unemployment and job-vacancy rates have been admirably low, a change in the skills demanded in the Swiss job market is evident in the divergent job-vacancy rates across industrial 
sectors. Vacancy rates have tended to be highest in high-skilled sectors like finance, and information and communications technology (ICT), as well as manufacturing. Shortages of engineers have been also enduring (Economiesuisse, 2017). Moreover, it is in these sectors that vacancy rates have also increased most rapidly over the past eight years, most notably in the ICT sector (Figure 5, Panel A). The new OECD Skills for Jobs indicators also point to particularly high skills shortages for information and communications technicians as well as health-related professionals and personal care workers. Shortages of ICT workers are not unique to Switzerland, with ICT-sector vacancies increasing across most of Europe (Panel B). Beyond illustrating the growing gap domestically, shortages that are common to Europe mean that Switzerland is unable to attract workers it needs with these skills from other European countries in sufficient numbers (despite paying a wage premium), as it has for other sectors thanks to the free movement of people agreement with the European Union (Swiss Confederation, 2017; SECO, 2017). The share of foreign workers is highest in natural sciences, medicine and pharmacy, and engineering (Economiesuisse, 2017).

Figure 5. Job vacancy rates by sector in Switzerland and in the ICT sector across Europe

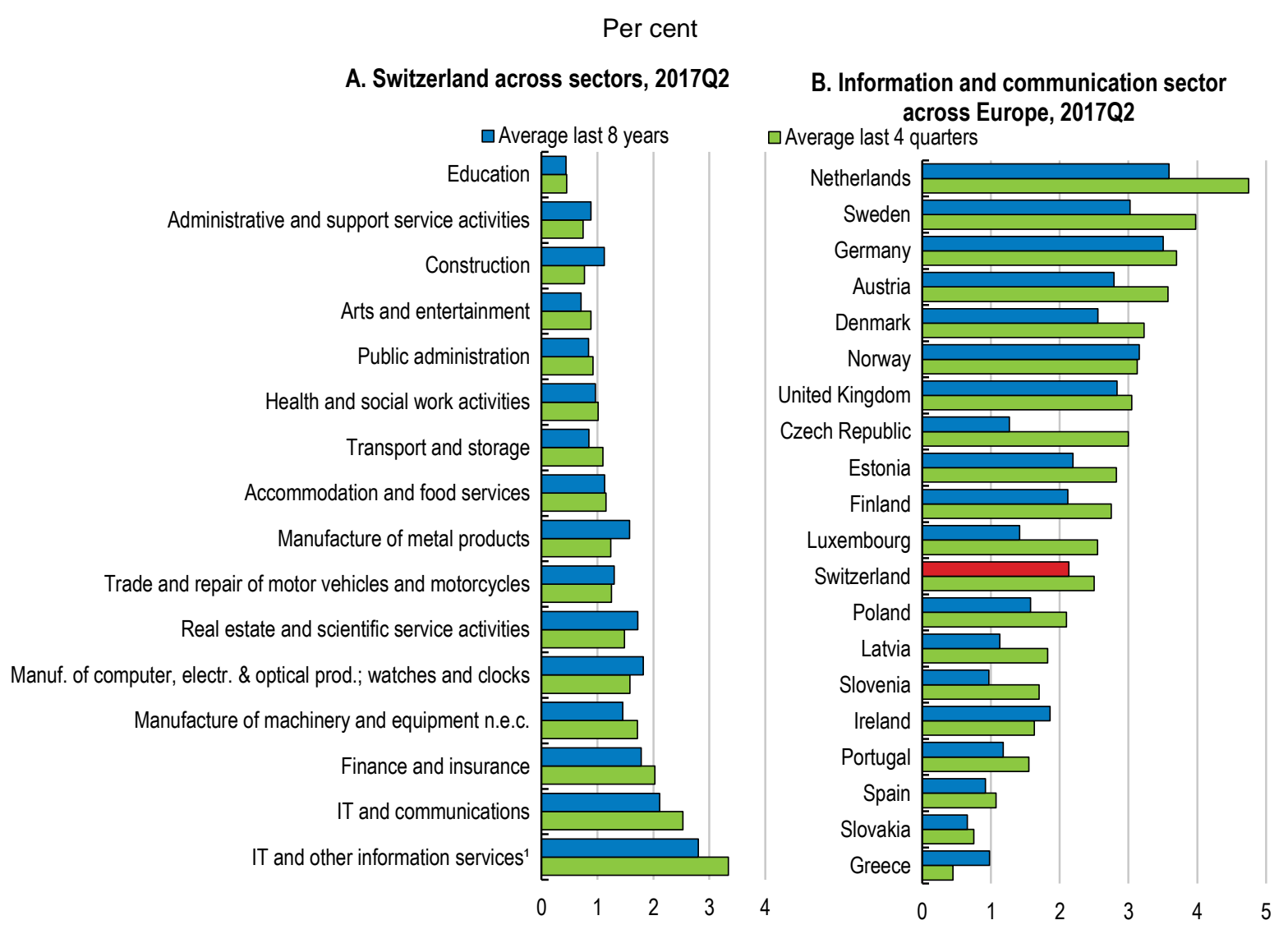

1. IT and Other Information Services is a subsector of IT and Communications.

Source: Federal Statistical Office; Eurostat.

In addition to rising vacancies in certain sectors, there is growing evidence of increased labour market mismatches. According to the EY Mid-Market Barometer (February 2017), the lack of qualified personnel remains a problem, with $61 \%$ of surveyed firms reporting difficulties in recruiting suitable employees. Shortages particularly affect technical manufacturing and the services sector, with $65 \%$ of firms reporting that they were finding it rather difficult or very difficult to find adequately qualified new staff. Furthermore, according to labour force data, $37 \%$ of workers in Switzerland were inappropriately skilled 
for their jobs in 2015, being either over- or under-qualified, up from 28\% in 2006 (Figure 6, Panel A; OECD, 2016c). Swiss qualification mismatch is mostly due to under-qualification, which contrasts with neighbouring Austria where over-qualification prevails. The share of part-time workers who are mismatched is 20 percentage points higher than that of full-time workers (OECD, 2017b). Mismatch is also higher for foreign-born workers. In contrast, only $13 \%$ of workers were employed in a different field of study than their specialisation, which is the lowest across countries included in the study (Panel B).

Figure 6. Types of mismatch in Europe

Percentage of employed aged 15-64, 2015

A. Qualification mismatch ${ }^{1}$
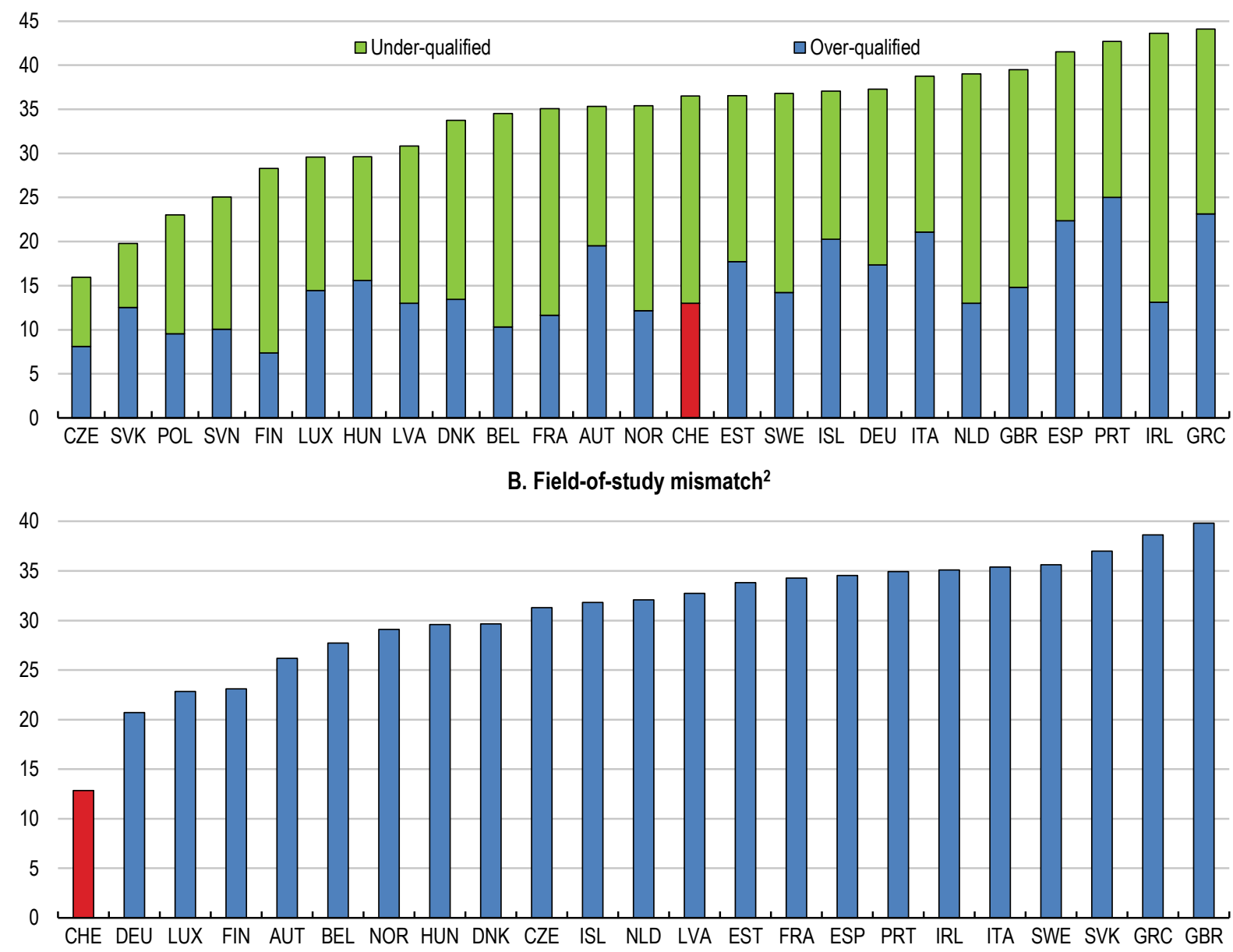

1. Qualification mismatch arises when workers have an educational attainment that is higher or lower than that required by their job. If their education level is higher than that required by their job, as measured by the modal level of qualification, workers are classified as over-qualified; if the opposite is true, they are classified as under-qualified.

2. Field-of-study mismatch arises when workers are employed in a different field from what they have specialised in.

Source: OECD, Skills for Jobs database.

It is hard to come to grips with precisely what is driving the skills mismatch in Switzerland, how this contributes to divergent vacancies across industrial sectors and the role of skills training. Better measures of skills mismatch can be constructed from the OECD Survey of Adult Skills (PIAAC), but, as mentioned, Switzerland did not participate. It did participate in the 2003 Adult Literacy and Life Skills Survey 
(Box 2), which showed a strong relative performance in numeracy and problem solving but less so in literacy.

\section{Box 2. The 2003 OECD Adult Literacy and Life Skills Survey}

Switzerland participated in the OECD's 2003 Adult Literacy and Life Skills Survey (ALL). The skills measured in the ALL survey included prose literacy, document literacy, numeracy and problem solving, and it covered the population aged 16 to 65 . Additional skills assessed indirectly included familiarity with and use of information and communications technologies. Although the range of countries surveyed was very limited (Bermuda, Canada, Italy, Norway, the United States and Switzerland), Switzerland nevertheless performed relatively well, particular in numeracy and problem solving (Figure 7). Also, within all domains Switzerland exhibited relatively little variance. Nevertheless, the skills gradient across age groups was as steep as in the other surveyed countries. While in general women performed less well than men across the subject areas, the Swiss gender gap was smaller than in the other countries.

The Survey showed that individual differences in upper-secondary attainment status are strongly related to differences in observed skills. Indeed, compared to other countries, Norway and Switzerland displayed, on average, the highest skills proficiencies associated with each additional year of schooling beyond upper-secondary education. That said, while participation in adult learning improved significantly in the 1990s, those with low skills and levels of education lagged behind.

How skills are rewarded varied considerably even across the small sample of countries. The ALL Survey suggested that in Switzerland extra skills are rewarded only if there is a commensurately higher level of education that is to say that skills are rewarded only in so far as adults who have completed additional years of schooling also have higher skills proficiencies. This highlights the importance of formal qualifications for employment in Switzerland.

Overall, the ALL results for Switzerland are quite idiosyncratic, perhaps reflecting its unique education system and industrial structure. This makes it difficult to infer specific lessons for Switzerland from the recent PIAAC Survey by comparing it with seemingly "peer" countries.

Figure 7. Adult Literacy and Life Skills Survey (ALL) scores, 2003

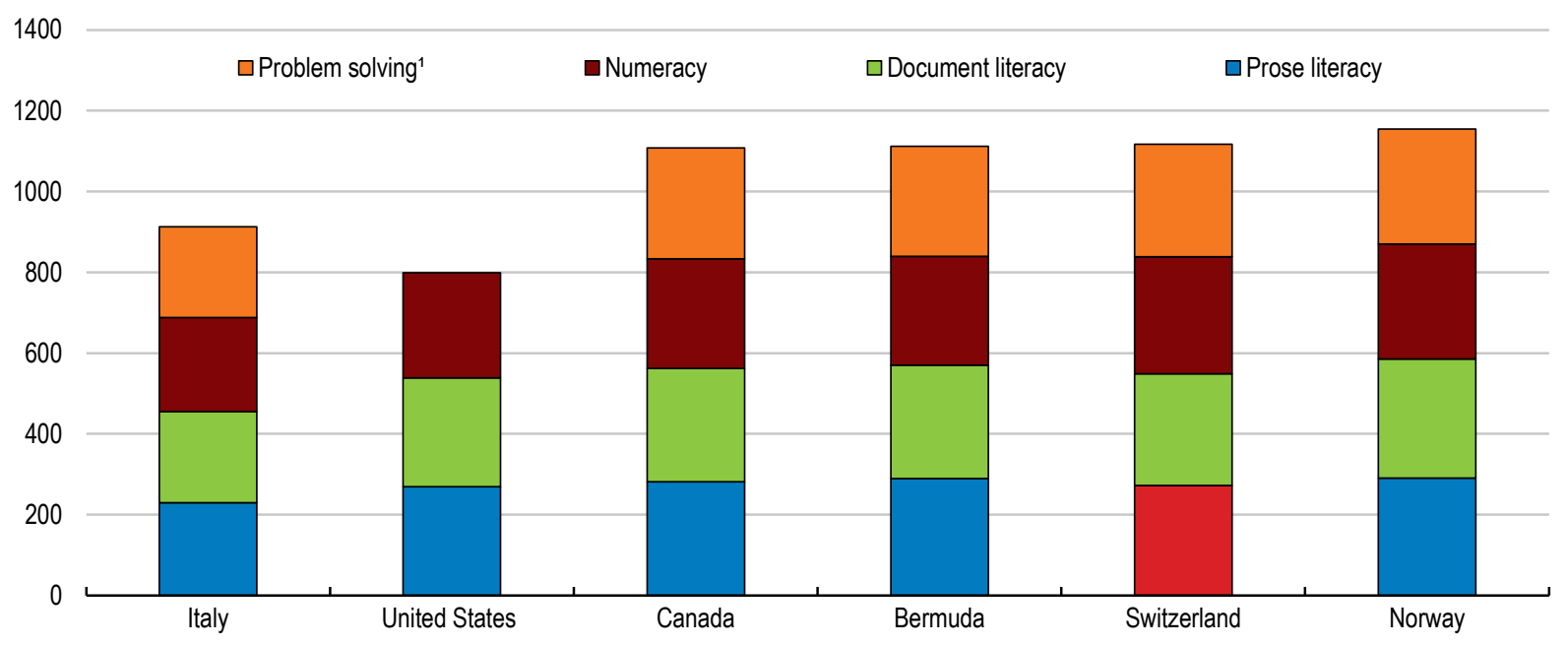

1. The United States was not surveyed on problem solving.

Source: OECD (2005), Learning a Living: First Results of the Adult Literacy and Life Skills Survey, OECD Publishing, Paris.

Richer data on the distribution of Swiss workers' skills would allow policy-makers to fine-tune the system. A first step would be to participate in the next round of PIAAC. PIAAC results have been instructive in formulating skills policy in other OECD countries. For example, they have been used to answer questions such as how the mix and content of vocational programmes are determined with 
reference to labour market needs; and how to build core academic skills (particularly literacy and numeracy) into vocational programmes. The results have helped answer questions about how to construct effective avenues of progression from initial vocational programmes to both higher-level vocational and academic curricula and the role of work-based training. PIAAC also provides guidance on how skills including digital skills - are assessed, certified and used and how qualifications can reflect labour market needs that are nationally consistent but flexible enough to allow for locally negotiated elements.

The true significance of differing vacancy rates, shortages or skills mismatches across sectors is hard to gauge because of the openness of the Swiss labour market to inflows from abroad since the free movement of people agreement with the European Union was enacted in 2002. This is in addition to standard methodological and data issues that complicate measurement of shortages and mismatch. For instance, a low vacancy rate in a certain sector, be it high- or low-skilled, may disguise a mismatch between the demand for these skills and their domestic supply: it may just mean that Switzerland has been more successful in attracting workers in these sectors from abroad. Indeed, Switzerland has consistently attracted large inflows of high-skilled workers (Table 1; OECD, 2013 and 2015a). While low-skilled immigration was significant prior to the crisis, workers with an upper-secondary education or non-tertiary degree are now a more significant source of population growth (Table 2.1). Empirical studies have found insignificant or small effects of the EU agreement on overall native-born labour market outcomes (Basten and Siegenthaler, 2013; Gerfin and Kaiser, 2010; Beerli and Peri, 2015). There is some evidence that high skilled workers' wage growth may have been affected. Overall, the fact that native-born labour market participation rose, as did real wages, suggests that migrants have probably helped meet labour market needs and facilitated economic growth (Swiss Confederation, 2017).

Table 1. Sources of working-age population growth

By education and nationality, at June of year shown

\begin{tabular}{|c|c|c|c|c|c|}
\hline & \multicolumn{2}{|c|}{$\begin{array}{l}\text { Share of working-age } \\
\text { population (\%) }\end{array}$} & \multicolumn{3}{|c|}{$\begin{array}{l}\text { Contribution to working-age population } \\
\text { growth over period shown (\% points) }\end{array}$} \\
\hline & 1997 & 2017 & $1997-2017$ & 1997-2007 & $2007-2017$ \\
\hline Swiss & 81.3 & 76.0 & 11.3 & 5.2 & 5.7 \\
\hline Lower secondary & 19.1 & 12.2 & -4.2 & -1.5 & -2.5 \\
\hline Upper secondary & 48.6 & 38.1 & -2.2 & -0.3 & -1.7 \\
\hline Tertiary & 13.7 & 25.7 & 17.7 & 7.0 & 9.8 \\
\hline Other nationalities & 18.7 & 24.0 & 10.6 & 3.3 & 6.7 \\
\hline Lower secondary & 7.0 & 7.5 & 2.1 & 1.0 & 1.0 \\
\hline Upper secondary & 8.0 & 8.3 & 2.1 & 0.4 & 1.6 \\
\hline Tertiary & 3.6 & 8.2 & 6.4 & 1.9 & 4.1 \\
\hline $\begin{array}{l}\text { Cumulative growth in the } \\
\text { working-age population (\%) }\end{array}$ & & & 21.9 & 8.5 & 12.4 \\
\hline
\end{tabular}

Source: Federal Statistical Office.

\section{The impact of digitalisation on work}

Digitalisation, computerisation and automation are likely to continue to have a dramatic impact on the structure of OECD country economies and labour markets in the coming decades, including on jobs in production, transportation and logistics, services and sales, as well as a wide range of administrative support and office occupations. Since the first industrial revolution around 1750, innovative technologies have displaced workers from many jobs. But also, like then, today's new technologies are creating new tasks, occupations and industries, and are requiring new skills at a faster pace than before. Digital skills gaps across the workforce will need to be reduced so that some groups, such as older workers, are not left behind (OECD, 2017c). The overall impact on employment is therefore ambiguous. Indeed, as evidenced by the trend decline in labour's share of income over recent decades in many OECD countries, there is 
strong evidence that technological change is capital-biased (Berger and Frey, 2016). This means that each worker works with a greater quantity and quality of capital, and working with the new technologies embodied in that capital requires new skills. However, a puzzle in the Swiss case is that the capital deepening has not occurred, at least not according to aggregate data (Ollivaud, 2017).

Among OECD countries, Switzerland already has one of the highest shares of jobs engaged directly in the ICT sector, at around 3.9\% of total employment, higher than in the United States (3.1\%) and Germany (2.9\%) (Figure 8). Likewise, IT specialists represented 5.0\% of total employment in 2016, the fourthhighest share in the OECD. In recent years the ICT sector has played a significant part in the evolution of labour productivity growth, both through growth in the overall sector and reallocation towards the highproductivity sector. Indeed, it is one of the most productive in the OECD (Figure 9). However, falling labour productivity within the IT services sector has dragged on labour productivity growth in the sector more broadly (Ollivaud, 2017). Furthermore, over the past decade and a half, labour productivity growth in Switzerland's ICT sector has not been as strong as in many other European countries.

This is not to deny that digitalisation and the related automation can substitute for parts of or entire jobs and thus lead to job losses. Studies estimate that $35-60 \%$ of EU jobs are at risk due to digitalisation-induced automation, with medium-skilled jobs, such as office and administrative support work, manufacturing, and transportation considered to be most at risk (Frey and Osborne, 2013). Based on its occupational mix, Switzerland may be particularly exposed to the impact of digitalisation on jobs over the forthcoming decades. Some studies estimate that roughly half of all jobs in Switzerland are highly susceptible to automation, on a par with the United States, while it is $42 \%$ in Germany and 35\% in the United Kingdom, Denmark and Finland (Berger and Frey, 2016; Deloitte, 2015; ETLA, 2014; Frey and Osborne, 2013 and 2014).

Figure 8. Employment in the ICT sector and its sub-sectors ${ }^{1}$

Per cent of total employment, 2015

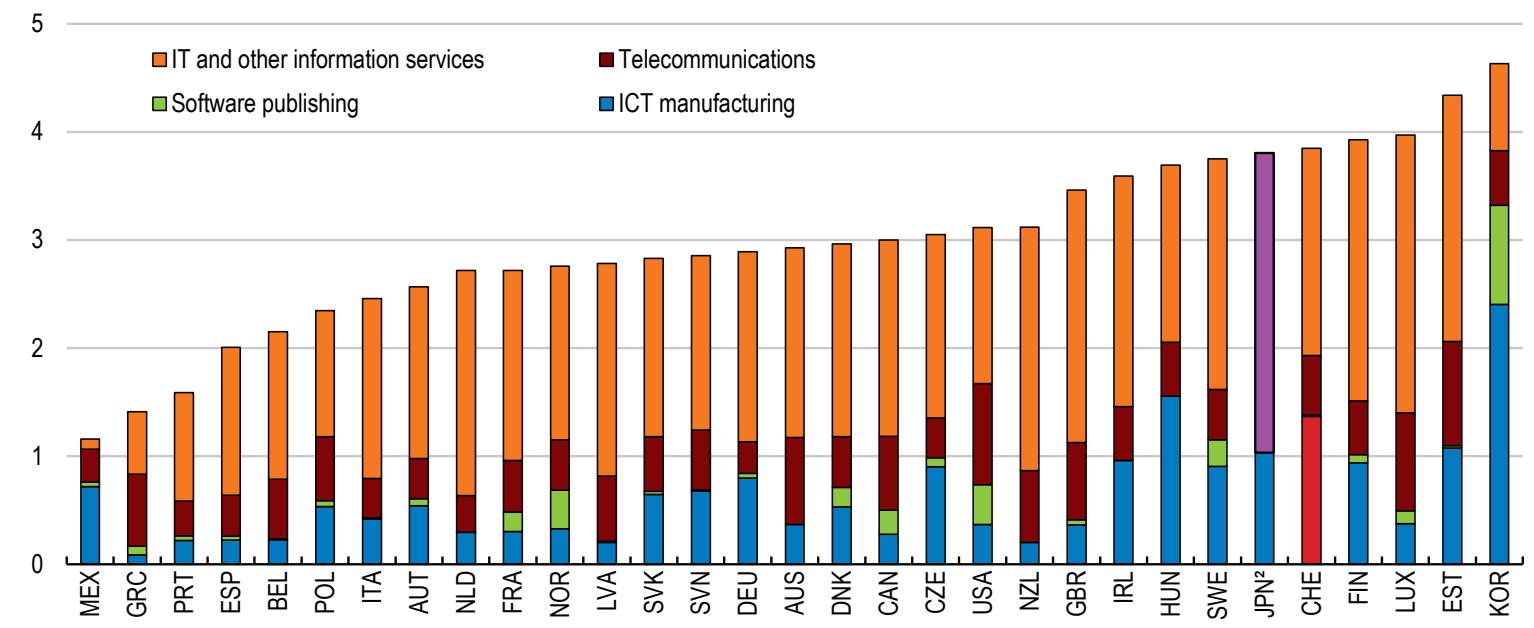

1. The ICT sector is defined here as the sum of industries ISIC rev.4 26, 582, 61 and 62-63. For France, Germany, Latvia, Lithuania, Spain, Sweden and Switzerland, data refer to 2014.

2. A breakdown of ICT services is not available for Japan.

Source: OECD (2017), Digital Economy Outlook 2017. 
Figure 9. Labour productivity in the ICT sector is high

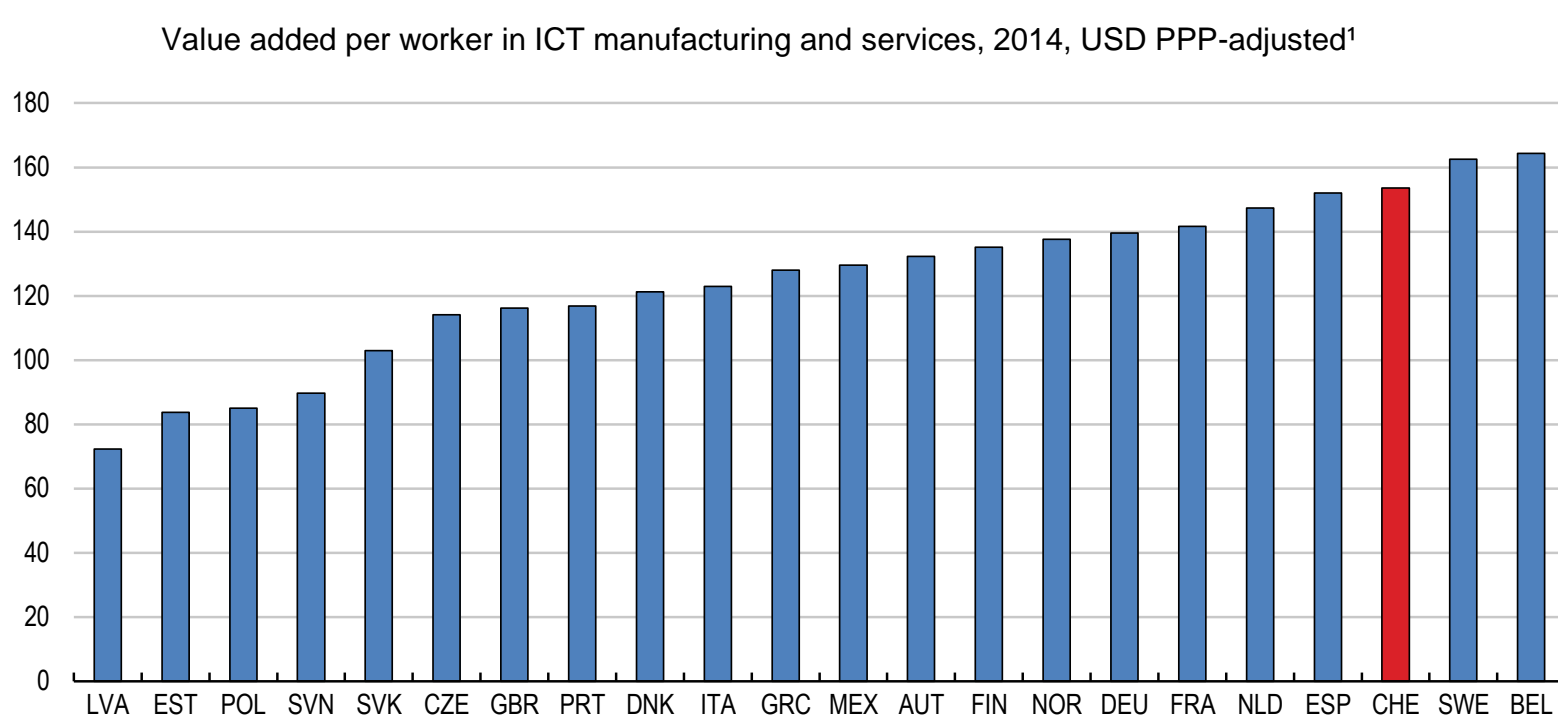

1. Updated data for Switzerland to reflect upward revisions to value added and employment are not yet available.

Source: OECD, STAN industrial analysis database.

Arntz et al. (2016), however, sound a note of caution: the aforementioned studies assume that whole occupations rather than single job-tasks are "automatable", an assumption that may over-estimate job "automatibility", as occupations labelled as high-risk often still contain a substantial share of tasks that are hard to automate. Using a task-based instead of a broader occupation-based approach, they find that only $9 \%$ of jobs are automatable on average across 21 OECD countries. Unfortunately, as it did not participate in PIAAC, no such estimate is available for Switzerland. Nevertheless, the PIAAC conclusions can be generalised to any country: less qualified workers are likely to bear the brunt of the adjustment costs as the automatibility of their jobs is higher than those of highly qualified workers. In Austria and Germany $30 \%$ of all jobs are at risk of significant change (in addition to those at risk of disappearing), compared to an average of 25\% across OECD countries (Arntz et al., 2016). The challenge is thus to cope with rising income inequality and ensure sufficient training and retraining, especially for less-qualified workers.

While automation has tended to benefit higher-skilled workers, there is evidence that it is routinebiased, so that technology seems a better substitute for average-paid clerical and manufacturing jobs than for personal service jobs at both the top and bottom end of the professional skills range. Oesch and Menés (2010) analyse occupational change over the last two decades in Britain, Germany, Spain and Switzerland and find that massive occupational upgrading at the top end matches educational expansion. That is, employment expanded most at the top of the occupational hierarchy: among managers and professionals in business and social services. However, in parallel, intermediate occupations (such as clerks and manufacturing workers) shrank relative to those at the bottom (personal service workers). While the surge in high-skilled jobs is consistent with the evolution of skills on the supply side and a skill-biased version of technological change on the demand side, the authors argue that this labour market polarisation with a Ushaped pattern of upgrading alongside hollowing out of the middle is consistent with the "routinisation" hypothesis.

It is important not to lose sight of the very strong likelihood that technological change will also generate additional jobs through demand for new technologies and through potential gains in competitiveness (not to mention the second-round effects of higher productivity and wages). The policy 
challenge in the face of digitalisation and automation is therefore twofold. The first is to cushion the impact of rapid structural change on people's lives. And the second is to ensure that those losing the 'old' jobs have the skills and the opportunities to undertake the 'new' ones and that those just joining the labour force are suitably prepared. This undoubtedly means equipping them with the right education and skills. For example, in the near future, it is expected that new jobs will increasingly have a technology component to them. This does not mean, however, that the focus should be entirely on core science, technology, engineering and mathematics (STEM) fields or computer programming. What will increasingly be needed is good training in basic technology competence combined with the ability to think critically and analytically and to work collaboratively and flexibly (OECD, 2016d and 2017c). To increase take-up of STEM fields, some OECD countries have altered the school curricula to improve preparedness for later studies in science and maths.

The Swiss economy is also highly exposed to foreign demand, with $36 \%$ of jobs depending on it, compared to $29 \%$ in the average OECD country. In manufacturing and financial intermediation the share was a little over $60 \%$. Similar skills will be needed to adapt to changes in globalisation as for digitalisation: basic skills like literacy, numeracy and problem solving, as well as management and communication skills and a willingness to keep learning (OECD, 2017d). Continuing to invest in skills development will also help countries gain more from greater participation in global value chains.

\section{Overview of the Swiss education system}

Whether the Swiss system of education is well designed to accommodate the process of digitalisationand automation-induced structural change is worthy of exploration. This section will start with an overview of the education system as a whole and then focus specifically on the skills mix it generates and whether it is both appropriate and sufficiently flexible in the face of rapid change.

One defining feature of Swiss education, reflecting the decentralised nature of the political system, is that there is no single dedicated federal Ministry of Education. However, the main responsibilities at the federal level responsibilities lie with the Federal Department of Economic Affairs. The cantons are responsible for compulsory education, which generates differences across cantons and makes co-ordination more difficult. Likewise, the division of responsibilities for non-compulsory education between federal and cantonal levels creates challenges for co-ordination (Table 2). To address these challenges, there are multiple co-ordinating bodies, including the Swiss Conference of Cantonal Ministers of Education (between cantons), the Swiss Conference of Higher Education Institutions (between the confederation and cantons), the Swiss Conference of Rectors of Higher Education Institutions and the Swiss Accreditation Council. The Continuing Education and Training Act that came into effect in 2017 aims to improve coordination in that domain.

Given that the cantons are responsible for compulsory education, there is some variation in regimes across the country. In general, children do two years of kindergarten starting at the age of four, and in most cantons two years of kindergarten are now compulsory. Primary school begins at six. In total, the two levels of compulsory schooling - primary and lower secondary - last for nine years in most cantons. A 2009 initiative, called the HarmoS programme, was developed to make cantonal education more consistent throughout the country. However, variations still exist between cantons, and certain areas have voted not to conform to these regulations.

Public compulsory education is free of charge for all children. Public institutions are attended by $95 \%$ of children, with only a small (but growing) minority attending private schools. Pupils with different developmental statuses, capabilities, social circumstances, linguistic backgrounds and behavioural characteristics all attend the same school. This heterogeneity regarding pupils' capabilities and talents, along with the cultural heterogeneity in the classes, poses challenges for schools. While similar challenges 
exist in all OECD countries, in Switzerland where children of non-Swiss "origin" make up around onequarter of the student population in the compulsory system, it is particularly apposite.

Table 2. Responsibilities for non-compulsory education

\begin{tabular}{|c|c|c|}
\hline & Confederation $^{1}$ & Cantons \\
\hline Upper secondary & $\begin{array}{l}\text { Regulation and co-funding (SERI) of } \\
\text { vocational education and training } \\
\text { (funding is mostly private) } \\
\text { Providing basic and continuing training to } \\
\text { teachers, trainers, instructors and } \\
\text { examiners (SFIVET) } \\
\text { Responsible with cantons for Swiss-wide } \\
\text { recognition of the Baccalaureate }\end{array}$ & $\begin{array}{l}\text { Provision, supervision and } \\
\text { funding } \\
\text { Inter-cantonal regulations apply } \\
\text { for the recognition of upper- } \\
\text { secondary specialised schools } \\
\text { and their qualifications }\end{array}$ \\
\hline $\begin{array}{l}\text { Professional tertiary } \\
\text { education } \\
\text { - Federal examinations } \\
\text { - Colleges of higher education }\end{array}$ & $\begin{array}{l}\text { Strategic planning, regulation (SERI) } \\
\text { Providing basic and continuing training to } \\
\text { teachers, trainers, instructors and } \\
\text { examiners (SFIVET) } \\
\text { Co-funding }\end{array}$ & $\begin{array}{l}\text { Most funding } \\
\text { Some provision via colleges }\end{array}$ \\
\hline \multicolumn{3}{|l|}{ Academic tertiary education } \\
\hline $\begin{array}{l}\text { - Universities of Applied } \\
\text { Sciences }\end{array}$ & Co-funding for projects & Regulation and most funding \\
\hline $\begin{array}{l}\text { - Universities of Teacher } \\
\text { Education }\end{array}$ & Regulation and co-funding & Most funding \\
\hline - Universities & Some co-funding & $\begin{array}{l}\text { Regulation, funding and } \\
\text { management }\end{array}$ \\
\hline $\begin{array}{l}\text { - Federal Institutes of } \\
\text { Technology }\end{array}$ & Regulation, funding and management & \\
\hline $\begin{array}{l}\text { Continuing education and } \\
\text { training }\end{array}$ & $\begin{array}{l}\text { Regulation and promotion (but mostly } \\
\text { privately funded) }\end{array}$ & $\begin{array}{l}\text { Provision of some training } \\
\text { programmes }\end{array}$ \\
\hline
\end{tabular}

In lower secondary school, at around the age of 12, classes typically become grouped based on ability. This decision is largely made on the basis of students' academic ability, which is assessed by academic performance with the subjective assessment of their teachers and sometimes parental input. There may also be an exam. Then in upper secondary school, at around age 15, the education system separates into two streams: general (academic) and vocational, as in Germany and Austria.

At the age of 15, Swiss students perform well in international comparisons, although, as with Luxembourg, this comes at a higher per-point cost than in most other OECD countries, suggesting strongly decreasing returns after a certain level of per student spending (Figure 10). Swiss students perform well in mathematics and science but less so in reading. And in line with many other countries boys outperform girls in mathmatics and science, while girls perform better in reading (Table 3). 
Figure 10. PISA outcomes versus expenditure per student
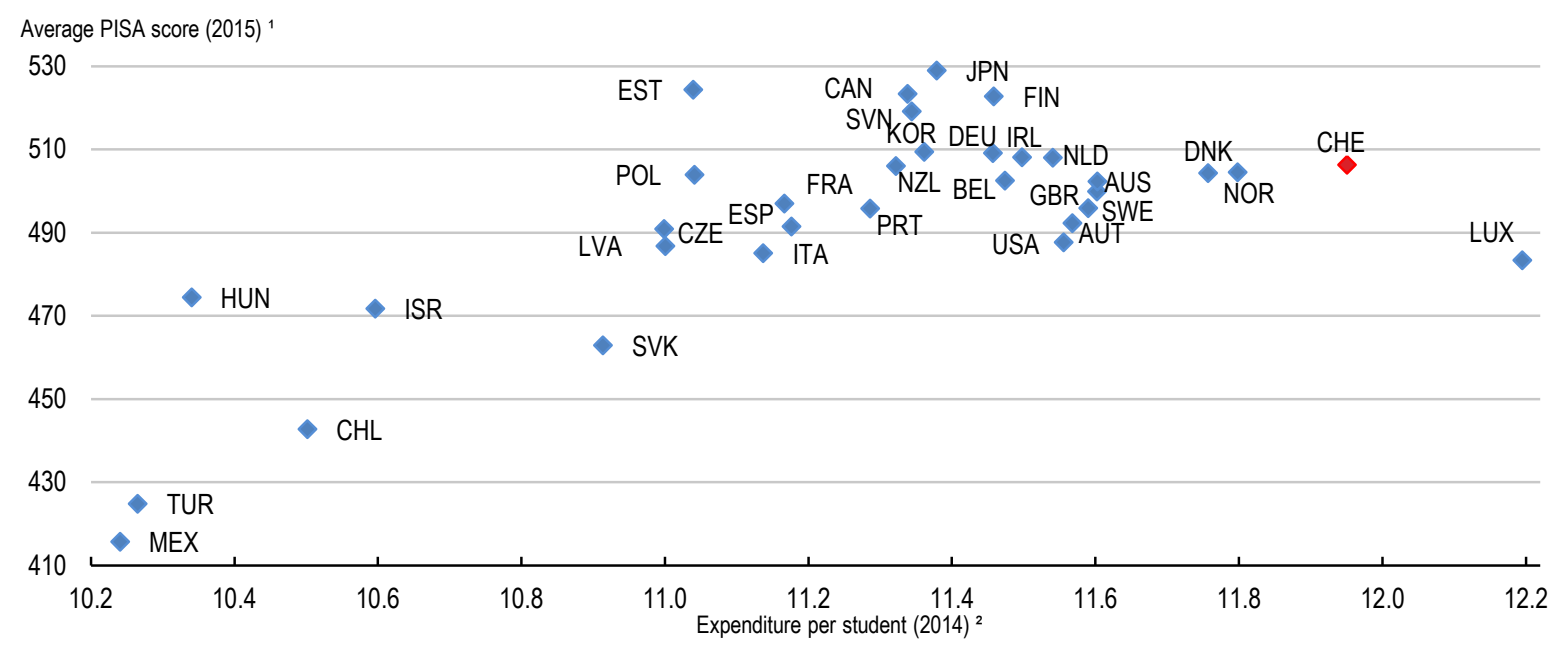

1. Average of reading, science and mathematics scores.

2. Cumulative expenditure per student by educational institutions over the expected duration of primary and lower secondary studies. In log of equivalent USD converted using PPPs.

Source: OECD (2016), Education at a Glance 2016.

Table 3. PISA scores and gender differences across selected countries

\begin{tabular}{|c|c|c|c|c|c|c|}
\hline & \multicolumn{2}{|c|}{ Mathematics } & \multicolumn{2}{|c|}{ Reading } & \multicolumn{2}{|c|}{ Science } \\
\hline & Level & $\begin{array}{c}\text { Gender } \\
\text { difference }\end{array}$ & Level & $\begin{array}{c}\text { Gender } \\
\text { difference }\end{array}$ & Level & $\begin{array}{c}\text { Gender } \\
\text { difference }\end{array}$ \\
\hline Switzerland & 521 & 12.0 & 492 & -25.3 & 506 & 6.1 \\
\hline Denmark & 511 & 9.4 & 500 & -22.2 & 502 & 6.0 \\
\hline Germany & 506 & 16.6 & 509 & -20.8 & 509 & 10.5 \\
\hline Austria & 497 & 27.0 & 485 & -20.2 & 495 & 18.8 \\
\hline France & 493 & 6.0 & 499 & -29.1 & 495 & 1.9 \\
\hline OECD average & 490 & 7.9 & 493 & -26.9 & 493 & 3.5 \\
\hline Italy & 490 & 19.9 & 485 & -16.0 & 481 & 17.0 \\
\hline Luxembourg & 486 & 11.3 & 481 & -21.3 & 483 & 7.6 \\
\hline
\end{tabular}

Note: Gender difference is boys' average score less girls' average score.

Source: OECD (2016), Education at a Glance 2016.

\section{Upper-secondary and tertiary education}

After nine years of compulsory schooling, the vast majority of young people in Switzerland continue on with upper-secondary education, be it in the vocational stream with apprenticeships and at vocational schools, or in the academic stream at baccalaureate schools leading mainly to universities. Many empirical studies find that, after the general level of cognitive skills is considered, years of both pre-tertiary and tertiary schooling seem to have little or no independent empirical effect on growth (Hanushek and Wößmann, 2008). In contrast, a variety of models, such as those of Vandenbussche et al. (2006) and Aghion and Howitt (2009), suggest that tertiary education is particularly important for countries near the technological frontier where growth requires new inventions and innovations. However, these studies do not make a distinction between types of tertiary education: academic or vocational or a mix thereof.

In Switzerland, the direction that students take in their upper-secondary studies is determined by which academic ability group they had attended in lower secondary school. Like many northern and 
eastern European countries, vocational education and training plays an important role in upper-secondary education, with over two-thirds of students opting for this stream. Around $12 \%$ opt for a transitional arrangement, delaying upper secondary education. Only $41 \%$ of young people in Switzerland are expected to graduate from general (academic) upper-secondary programmes, compared with an OECD average of 52\% (OECD, 2017a). Indeed, as of 2016, 46\% of Swiss 25-64 year-olds had ended their formal education with only an upper-secondary or post-secondary non-tertiary qualification, with the vast majority of these having a vocational rather than a general qualification (Figure 11). However, the share of 25-34 year-olds graduating from upper-secondary education has fallen to $45 \%$, from $64 \%$ in 2000 , suggesting that more and more Swiss students are choosing to invest in tertiary education, a trend that is also evident in Germany and Austria but to a much smaller degree (OECD, 2015b).

\section{Figure 11. Percentage of 25-64 year-olds whose highest level of education is upper-secondary or post-} secondary non-tertiary, by programme orientation (2016) ${ }^{1}$

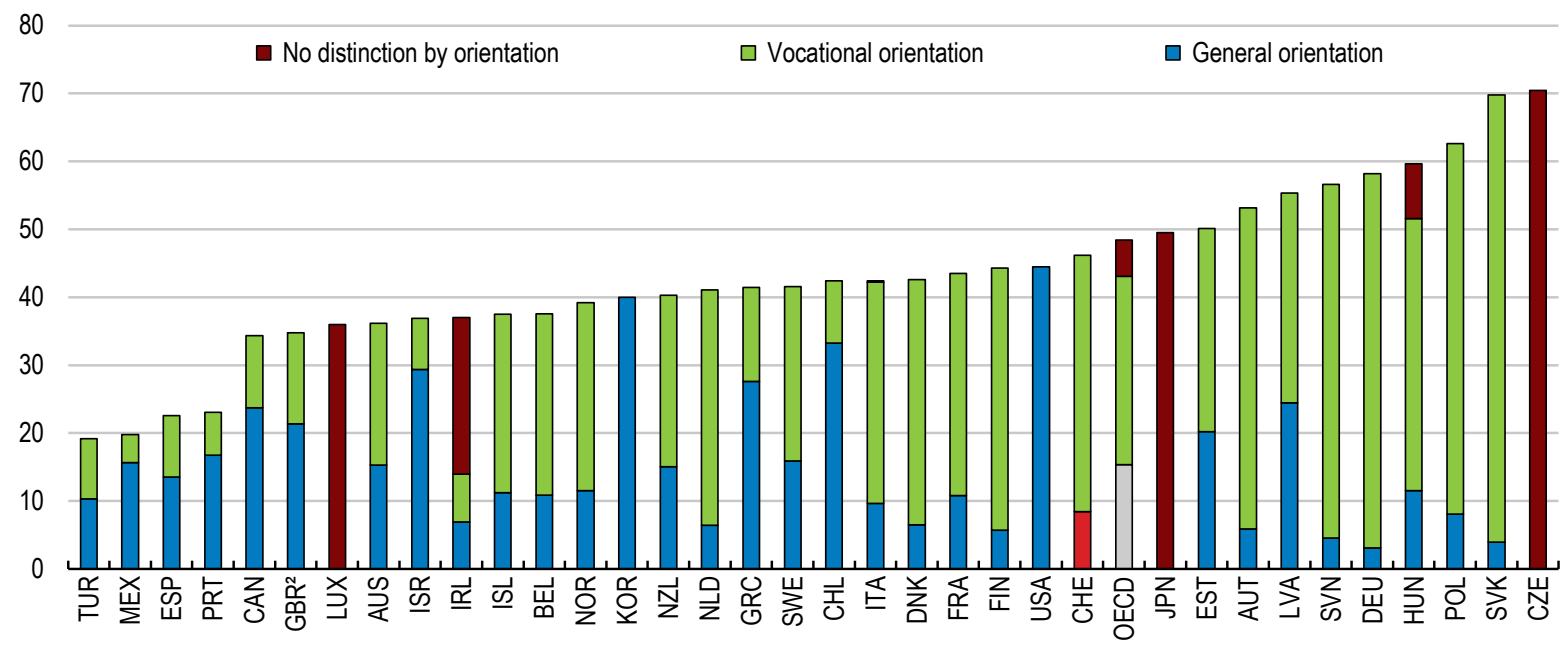

1. For Denmark, Finland, Ireland, Latvia, Lithuania, Luxembourg and Slovenia data for the breakdown by programme orientation are available only for 15-34 year-olds. Reference year is 2015 for Chile and Ireland.

2. The United Kingdom: data for upper-secondary attainment includes completion of a sufficient volume and standard of programmes that would be classified individually as completion of intermediate upper-secondary programmes (18\% of the adults are in this group).

Source: OECD, Education at a Glance database.

In 1997 the Swiss Confederation started to adopt laws concerning adult education, especially regarding vocational education and training. Since the 2004 implementation of the Vocational Education and Training Law and Decree, all areas of vocational education and training have had a uniform legal framework. This law takes into account the growing number of careers and introduces new qualification procedures. Additionally, much work has been done over recent decades to develop opportunities for those in the vocational track to continue on to tertiary education.

Until the mid-1990s, a transition from basic vocational education and training (VET) to academic tertiary-level programmes was next to impossible in Switzerland. Reforms in the 1990s transformed some tertiary-level professional education and training colleges and programmes into universities of applied sciences that are open to holders of a newly introduced professional baccalaureate. The professional baccalaureate, which is based on the Federal Certificate, typically extends VET duration by one year (Figure 12). Also in recent years there has been an attempt to address the perceived lack of permeability between the vocational and academic tracks with the introduction of pathways between the two parallel systems, allowing students to transition midstream. However, these links are still rarely utilised, as they are expensive in terms of lost time and opportunity cost. Today, about one eighth of each age cohort obtains a professional baccalaureate, and attendance at 
universities of applied science has contributed heavily to boosting enrolment in tertiary education, which previously had begun to lag international standards. Since the introduction of these reforms, Switzerland has shot ahead of its peers in terms of average years of tertiary schooling (Figure 13).

Figure 12. The post-compulsory education system

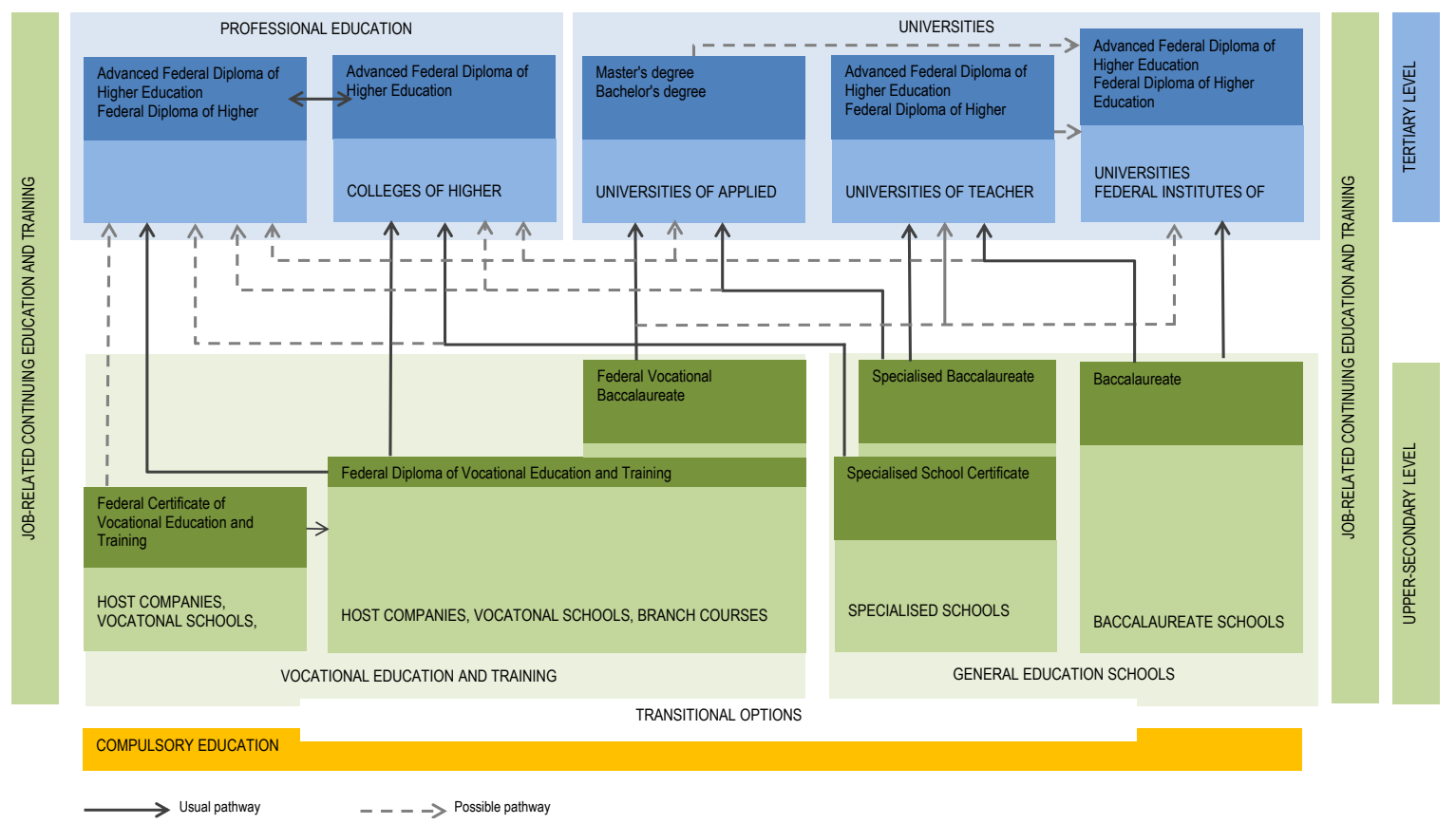

Source: Adapted from SERI (2016), Vocational and Professional Education and Training in Switzerland: Facts and Figures 2016.

Figure 13. Average years of tertiary schooling for the total population, 1950 to 2010

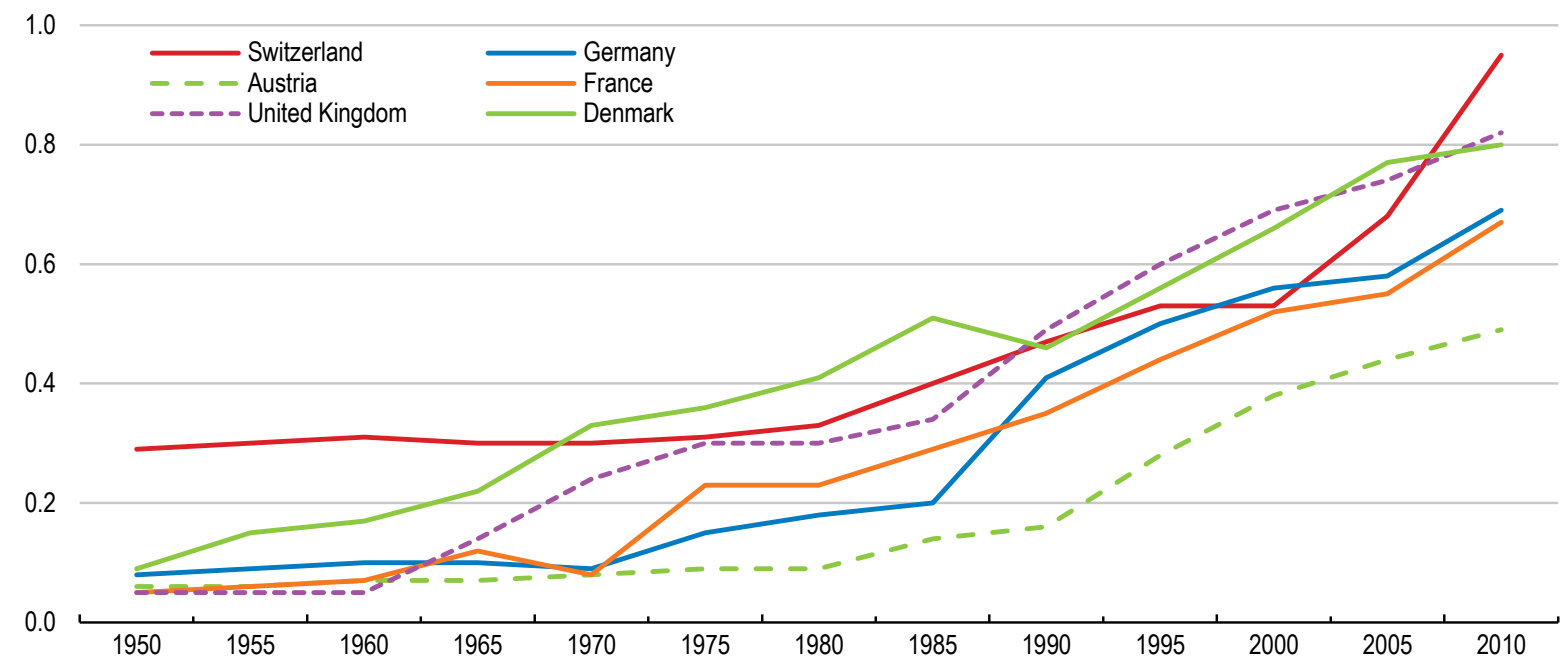

Source: Barro and Lee Educational Attainment Dataset (2016). 


\section{The vocational stream}

The Swiss vocational education and training system is complex and has become more so with a proliferation of pathways and extensions that offer greater opportunities for those within this stream to gain higher qualifications (Meyer, 2009). Moreover, there are certified vocational education and training programmes at the basic (upper-secondary) level for some 230 different professions. That said, a real advantage of the Swiss system is that the vocational stream has been responsive to the demands of the labour market, which has contributed to the notably smooth transition of young people into the labour force (Geel and Backes-Gellner, 2011). While an estimated 59\% of UK tertiary graduates end up with nongraduate jobs (close to highest rate of mismatch in Europe), in contrast less than a tenth of Swiss graduates end up in such jobs - the best performance in Europe in this regard, followed by Germany, the Netherlands and Slovenia (CIPD, 2015). It is perhaps no coincidence that these countries are all ones with a long history of high-quality VET.

After completing three years of lower-secondary school, students in the vocational stream can sign up for a two- to four-year apprenticeship. Potential apprentices go through a recruitment process, and a training contract is drawn up between the apprentice and the firm offering the apprenticeship. This contract is subject to the oversight of cantonal authorities, and the apprentice receives a modest monthly salary that is below a qualified employee's salary but increases each year. The programme typically involves a dual engagement of practical work and study. The study component takes place at vocational schools and typically involves one to two days a week.

To complete an apprenticeship, individuals need to take a final examination. After successfully completing the three- and four-year programmes, apprentices qualify with a Swiss federal vocational diploma, while those who successfully complete the two-year programme are awarded a Swiss federal vocational certificate (Figure 12). By combining the diploma for the three- and four-year apprenticeship with a Swiss federal vocational baccalaureate, students can also attain a vocational baccalaureate qualification, which allows them to enrol in a university of applied science or to prepare for the University Aptitude Test, allowing them to enrol in a cantonal university or federal institute of technology.

After completing an apprenticeship, students also have access to further study at a Professional Education and Training college. These colleges offer a broad spectrum of technical courses, which teach students the skills required to assume professional and management responsibilities in their field. The professional organisation for the relevant sector is responsible for organising and holding the examinations at the end of these courses.

\section{The supply of VET}

The strong labour-market matching outcomes of Swiss vocational education and training are in no small part attributable to the central role played by industry in managing the system. First, the supply of apprenticeships is by definition determined by employer needs. Second, VET study programmes are subject to regulation by a board of industry representatives. Every year the boards certify additional VET programmes, including their syllabi and qualification requirements. VET programmes must be reviewed every five years and updated at least every 10 years. New programmes can be created by a profession board interacting with the State Secretariat for Education, Research and Innovation and adjusting the plan as needed ahead of and following consultations with stakeholders. The State Secretariat ultimately approves the plan.

The collaboration with employers ensures a good match between industry demand and the supply of qualified workers, but it is unclear if this system is sufficiently responsive to the faster-paced changes digitalisation is expected to bring (SERI, 2017; Ecoplan, 2017). Creating or changing programmes can be 


\section{ECO/WKP(2017)76}

slow and could be sped up using time limits or streamlining processes. In the school-based VET system where school-to-work transitions are rougher due to weaker links with industry, linkages with employer associations should be strengthened further to better ensure training is meeting current and future labour market needs. More generally, the employer representatives on the profession boards are typically from incumbent firms and may be more focused on immediate needs rather than sufficiently anticipating developing trends. In this regard, it could be helpful to complement the existing framework with a mechanism that helps players in education and training, including these VET boards, to better forecast and anticipate shifts in the demand for skills. This would also inform education and labour market policies more broadly and complement existing skills assessments that focus on current needs. Box 3 details how some other OECD countries forecast skills needs.

\section{Box 3. Forecasting skills needs}

Occupational and educational forecasting has a long tradition in many OECD countries, including Australia, Canada, France, Germany, Italy, the Netherlands, the United Kingdom, the United States and, more recently, Finland, New Zealand and Israel. Forecasting is conducted by academic and government organisations, the private sector and increasingly at the international (e.g. European) level. Most forecasts rely on dynamic macroeconomic models and use a "top-down" approach to forecasting labour demand. Dynamic macroeconomic modelling has been labelled "best practice" in international skills forecasting, but there are limits to its effectiveness. These macroeconomic models require the specification of a large set of external parameters related to the development of the world economy, such as oil prices and exchange rates. A problem common to many of the reviewed forecasts is that it is difficult to forecast future migration and its skills composition.

In England, the UK Commission for Employment and Skills conducted a National Strategic Skills Audit in 2010, combining quantitative and qualitative methods in order to incorporate a broader "scenario-based" approach to assessing future skills needs. The overall intention of this ongoing project is to provide insights to government, employers, individuals and providers on England's strategic skills needs, reporting information on key issues and periodically updating the results. The project includes three main instruments:

Working futures: consists of quantitative forecasts of employment prospects for industries and occupations, qualification/level of diploma, gender and employment status for the United Kingdom, its individual nations and English regions. It aims to provide a comprehensive picture of the labour market in 2020.

Horizon scanning and scenario development: identifies key issues and changes taking place in the United Kingdom and globally that may affect employment and skills over the long term. It uses a range of horizon-scanning techniques, including scenario development and a series of interviews with key experts to contemplate scenarios for 2020.

Targeted skills assessment reports: in-depth skills assessments conducted in key emerging sectors to enhance understanding of important developing areas of the economy, such as low-carbon industries, digital sectors and advanced manufacturing.

Despite the different methodologies used in forecasting, the results are often similar. In general, low-skilled jobs are forecast to decline, while employment for highly skilled workers is projected to increase, though some projections indicate a future excess supply of highly skilled workers in some fields. The trend is for employment to continue to shift from primary and secondary industries towards service-based sectors.

Employers, too, can be involved in forecasting skills needs. For example in Finland, the Oivallus Project (Oivallus means literally "Insight") was launched by the Confederation of Finnish Industries (EK) in 2008 and ran until December 2011. The project, financed by EK, the European Social Fund and the Finnish National Board of Education, focused on future competence needs of businesses. Representatives from companies, academics and teachers and other experts examined the underlying premise that working life in 2020 will be even more networked. Oivallus found that competence needs are changing because the ways of working are changing, as jobs are becoming less and less routine and fewer jobs can be done "by the book". Future working lives resemble film-making: work is increasingly done on a project basis in collaboration with various contributors (commonly referred to as the "gig economy"). There is also a tendency for tasks to become more variable. The ability to apply network skills is the foundation of future work, and network skills find their application in the ability to find, use and disseminate knowledge. A learning network can identify new opportunities and find solutions to problems, where the key to success is the ability of people with 
different competences to work together. Working as a network, learning from one another and building on existing ideas are skills that require practice and should be developed from early on throughout education. For more information, see http://ek.multiedition.fi/oivallus/en/index.php.

Skills anticipation exercises typically forecast skills needs and/or skills supply over the medium term (two to five years), but a number of countries forecast scenarios over 10 to 100 years. For example, Austria's AMS Qualifications Barometer provides forecasts of up to three or a maximum of four years. Longer-term exercises are particularly common in the Nordic countries.

Source: OECD (2016), Getting Skills Right: Assessing and Anticipating Changing Skill Needs, OECD Publishing, Paris; OECD (2012), Better Skills, Better Jobs, Better Lives: A Strategic Approach to Skills Policies, OECD Publishing, Paris; E. Lüdemann (2012), Review of Recent Projections of Skill Supply and Demand at the National and European Level, Institute for Economic Research (Ifo), Munich.

The number of vocational training places has also become an important issue. The share of companies offering training declined from $23 \%$ in 1985 to $18 \%$ in 2008, partly due to a rapid increase in the number of very small companies (SKBF, 2014). According to SERI (2016), of those companies that could offer apprenticeships, only around $40 \%$ do so. Older data show that growth in training places has been biased in favour of handicraft and industrial professions, while services sector professions including ICT remained under-represented (Meyer, 2009). These findings are borne out by more recent data: recent editions of the April "Apprenticeship Barometer" (which surveys firms and students at the start of the apprenticeship allocation period) show that demand for apprenticeships has consistently exceeded supply in "health and social activities", "information", and "printing, design and arts". The growth in the number of small firms was partly responsible for the earlier decline in offers of training places due to their greater specialisation and lack of qualified apprenticeship trainers (SERI, 2016; SKBF, 2014). Facilitating shared apprenticeships between small firms, as in Germany and Austria, would lower administration costs (Kuczera, 2017). This could be through a greater co-ordination role for training centres or promoting joint apprenticeships more actively, whereby one of the firms leads the apprenticeship but does not need to take full responsibility.

The increasing role played by foreign firms in the economy has also been considered a risk to the supply of vocational training places (Ecoplan, 2017; Hoeckel et al., 2009). Muehlemann (2014) finds that large multinationals (those with more than 100 employees) have a higher training rate than corresponding Swiss firms, whereas the rate for small multinationals (having less than 50 employees) is less than half of that for their Swiss counterparts. One reason is that small multinationals are more specialised, but another barrier may be that many work in English. The canton of Zug created a pilot bilingual VET programme with federal government support in 2014, which will run to 2019. If it is found to be cost effective, other cantons could be supported in beginning similar programmes.

Census-based data show that even in 2000 over half of vocationally trained workers did not work in the profession in which they initially undertook their apprenticeship (Meyer, 2009). The combination of increased longevity and technological change means that workers will increasingly need to move between occupations. As mentioned above, during their lifetimes workers are more likely to move from the goodsproducing to the services sector. This phenomenon has been linked to the idea of 'deprofessionalisation' (Entberuflichung), also postulated in Germany, due to the rise of the services sector, the knowledge society, digitalisation and globalisation (Meyer, 2009). Although occupation-specific skills appear to help with school-to-work transitions, general skills appear to be linked with employability later in life (Hanushek et al., 2016; Hampf and Woßmann, 2016; Forster et al., 2016). However, it is less clear whether the effect is stronger in countries where vocational education and training dominates. Switzerland was not included in these studies, which were based on PIAAC data; other data suggest that the decline in employability may be less severe in Switzerland (OECD, 2017a). Nonetheless, the cross-country results and pace of labour market change imply that while vocational education and training has been a 
cornerstone of Swiss labour market success, the balance of occupational versus academic training should be assessed to ensure the labour force can continue to adjust to changing skills demands. To improve flexibility and adaptability of its vocational system, Austria introduced modular apprenticeships that comprise a base module, several main modules and a special in-depth module, which ensures that apprenticeships are built on a common base of fundamental skills and increases mobility between occupations (OECD, 2017e).

\section{The post-secondary education mix}

Labour market indicators suggest that, despite a lack of apprenticeship offers, demand for highly qualified labour considerably exceeds domestic supply. As seen above, vacancy rates in the high-tech, manufacturing and finance sectors are well above the national average, and climbing (see Figure 5 above). Over recent decades Switzerland has relied on migrant labour to fill these jobs, with more than half of all immigrants to Switzerland holding a tertiary degree. Indeed, as observed already in the 2013 Economic Survey of Switzerland, Switzerland draws in large numbers of both low- and high-skilled labour, and it has continued to do so (OECD, 2013). However, with recent slower growth in Switzerland and uncertainty created by the 2014 referendum that aimed to limit immigration, the inflow of higher-skilled workers has declined. There is a risk that this will continue, and the number of foreign-born residents leaving continues to rise as the euro area recovery gains pace. Moreover, in many high-skilled sectors vacancy rates remain high, despite the migratory inflows. Switzerland should therefore do more to boost its domestic supply of skills.

Despite the trend towards increasing tertiarisation of Swiss post-school education, participation still appears low compared to other OECD countries. The first-time entry rate of Swiss youth into bachelor's or equivalent courses is low by international standards at only around 38\% of under 25 year-olds in 2015 (excluding international students), although for all age groups the rate is around the OECD average, at 54\% (Figure 14, Panel A). The bachelor's (or equivalent) graduation rate is $45 \%$ excluding international students - the third-highest in the OECD. Even with the growth in universities of applied sciences, the likelihood of continuing to tertiary education following vocational education and training is still only a fraction of that for graduates from general education programmes. At the post-graduate level the Swiss entry rate is around average (Panel B). Interestingly, it ranks highest in terms of overall doctorate and other advanced research studies due to the significance of international students, who accounted for $54 \%$ of doctoral students, which was the OECD's second-highest share after Luxembourg (87\%) (OECD, 2017a). Supply could be expanded by making it easier to move between vocational and academic streams, for example by increasing the academic component of vocational education and the applied component of academic education. Strengthening linkages between higher education institutions and employers, including through closer co-operation in course design and facilitating linkages between students and employers, could help ensure that the academic stream produces the skills needed to meet changing labour market needs. 
Figure 14. Tertiary academic qualifications in OECD countries', 2015

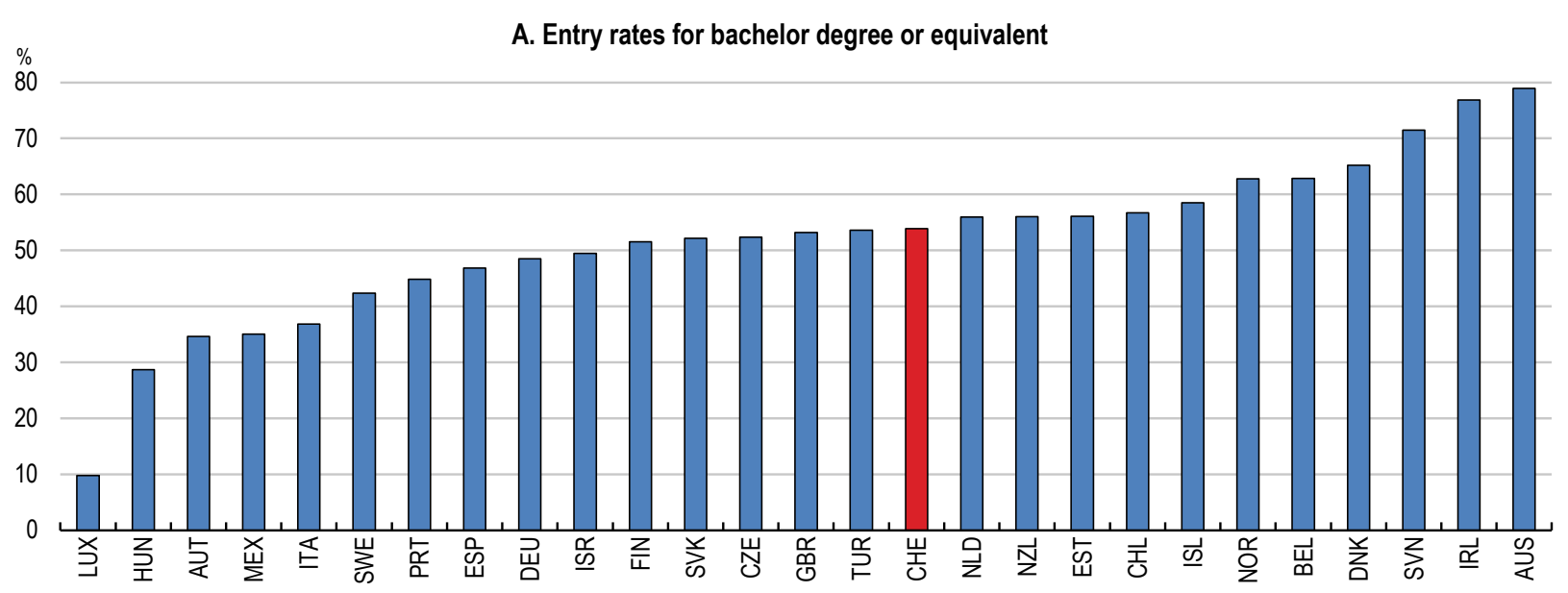

B. Entry rates for post-graduate degrees

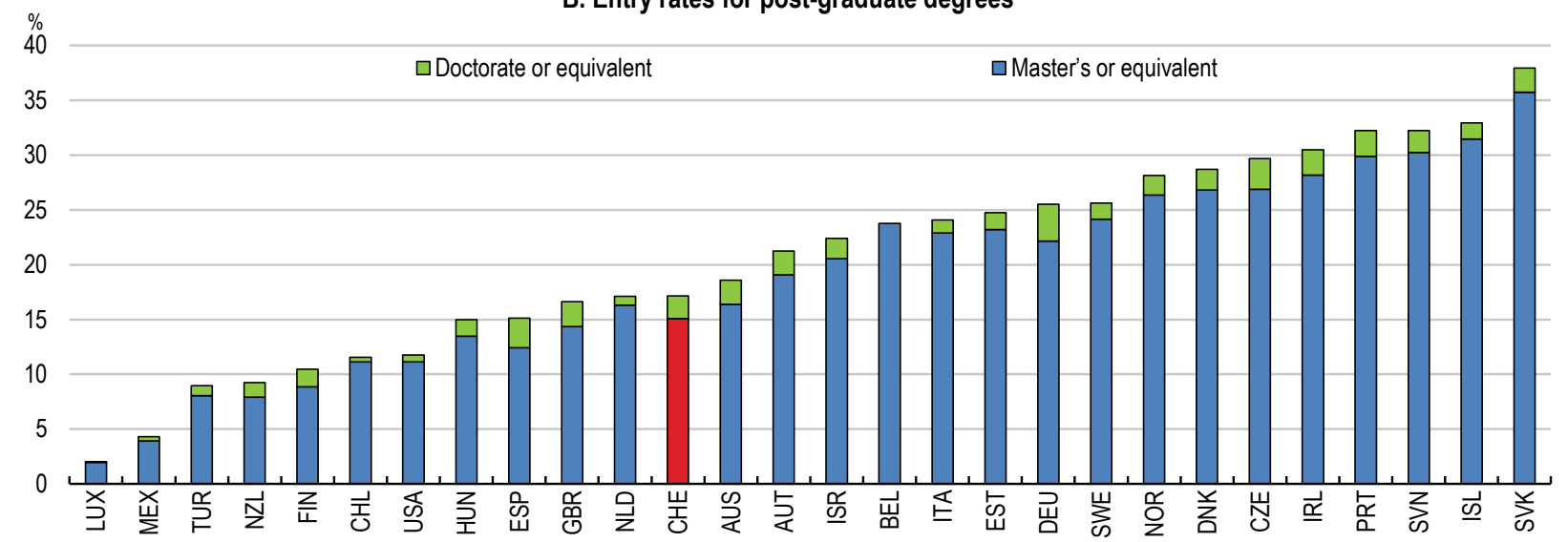

1. First-time entry rates, excluding international students. First-time entry rates indicate the share of young adults expected to enter that type of tertiary education programme during their lifetime.

Source: OECD (2017), Education at a Glance 2017.

\section{Life-long learning}

In addition to formal study preparing young people for their working lives, continuing adult learning must play an important role in the context of the evolving structure of the economy. On average across the OECD, at any point in time only around one-fifteenth of the working-age population is engaged in formal education. The others need to be catered for in terms of updating their skills in the face of the changing profile of skills demanded as the structure of the economy shifts. Not only is this true for people with jobs but also for those out of work and seeking to enter or re-enter the labour force - including mothers planning re-entry into the job market, migrants, people with low literacy and basic skills, or simply people rendered structurally unemployed as their previous jobs have disappeared (Windisch, 2015). The rapidly changing nature of ICT and digitalisation makes continued learning through courses, seminars and other types of non-formal training, in addition to formal education, increasingly important for enhancing workers' skills.

Continuing education and training (CET) does not appear to have been a priority objective for Swiss education policy until very recently, perhaps due to the relatively high rates of CET relative to other 
countries. It still receives only limited public funding. Spending by individuals is tax deductible, but this primarily benefits households with higher taxable incomes. Employers assume a large share of CET costs, whether in the form of financial support for direct costs or of permission to make use of paid working hours. Employer CET support is widespread, with about three-quarters of CET participants stating that they have been partly supported by their employer (SKBF, 2014).

In 2016 around one-third of all Swiss residents aged 25 to 64 surveyed had participated in some kind of CET course in the preceding four weeks (Figure 15, Panel A). This average figure is high by international comparison. However, as in other countries, training is generally concentrated in certain groups: the younger, the more educated, and those working in larger enterprises. The lower participation of less advantaged groups in Switzerland in continuing education is more ascribable to a lack of incentives to participate and support from employers than financial constraints themselves (SKBF, 2014). For instance, in 2016 adult participation (aged 25-64) in general and vocational education (in the preceding four weeks) was $45 \%$ for those with a tertiary degree, but only $11 \%$ for those with just compulsory education, giving rise to the largest difference in Europe (Panel B). Even though the share of the population with only a compulsory education is low, more should be done to increase their participation, as they would probably benefit substantially, including through greater resilience to future labour market changes. These workers may also be less aware of the benefits of continuing education and training. Changes to the legal framework (described below) will give the federal government authority to help address under-participation in some types of continuing education and training. Those who are working in a different profession to their field of study can face also barriers to formal training because their qualifications are not recognised.

Depending on the canton, general (non-job-related) CET can be regulated differently, e.g. based on a specific CET law, within the framework of the regulations on job-related CET, in laws on education and culture, or on another legal basis. Financing of job-related CET also differs across cantons. The cantons coordinate trans-regional CET programmes via the Inter-Cantonal Conference for Continuing Education and Training (IKW). The IKW is a specialist sub-group within the Swiss Conference of Cantonal Ministers of Education and acts in the interest of life-long learning.

At the federal level responsibilities for continuing education have been fragmented, reflecting the many types of continuing education but this is improving. Vocational continuing education is now the responsibility of the State Secretariat for Education, Research and Innovation (SERI). As part of the implementation of the Continuing Education and Training Act, responsibility for literacy policies will shift to SERI from the Federal Office for Culture, within the Federal Department of Home Affairs. The State Secretariat for Economic Affairs oversees continuing education programmes for the unemployed. Other federal offices are in charge of specific adult learning and education segments, such as the education of the disabled, migrants and the elderly.

A 2006 revision of the education regulations in the Federal Constitution (article 64a) gave the Confederation the authority to lay down principles of CET in law. The Continuing Education and Training Act finally came into effect in 2017 and should increase funding and co-ordination in the part of CET outside of the formal higher education sector. It establishes training as an individual's responsibility and that it should be market-based, but also that the Confederation and cantons should contribute to the accessibility of training and equality of opportunity. Importantly, it will facilitate data collection, which will help improve policymaking and access for all Swiss. This should be accelerated. Overcoming the fragmentation of responsibilities across departments and levels of government is crucial. The new Act provides an opportunity to establish an overarching approach. As of July 2017, 18 of the 26 cantons had agreed to sign performance agreements with the State Secretariat for Education, Research and Innovation to create a set of common strategic objectives to help adults acquire basic skills, but five had renounced participation. The aim is to ensure adults anywhere in the country can access local courses to acquire literacy, numeracy and ICT skills, with funding available to 2020 . 
Figure 15. Participation in life-long learning across Europe by educational attainment

Per cent of population aged 25-64 participating in education and training in the preceding four weeks, 2016

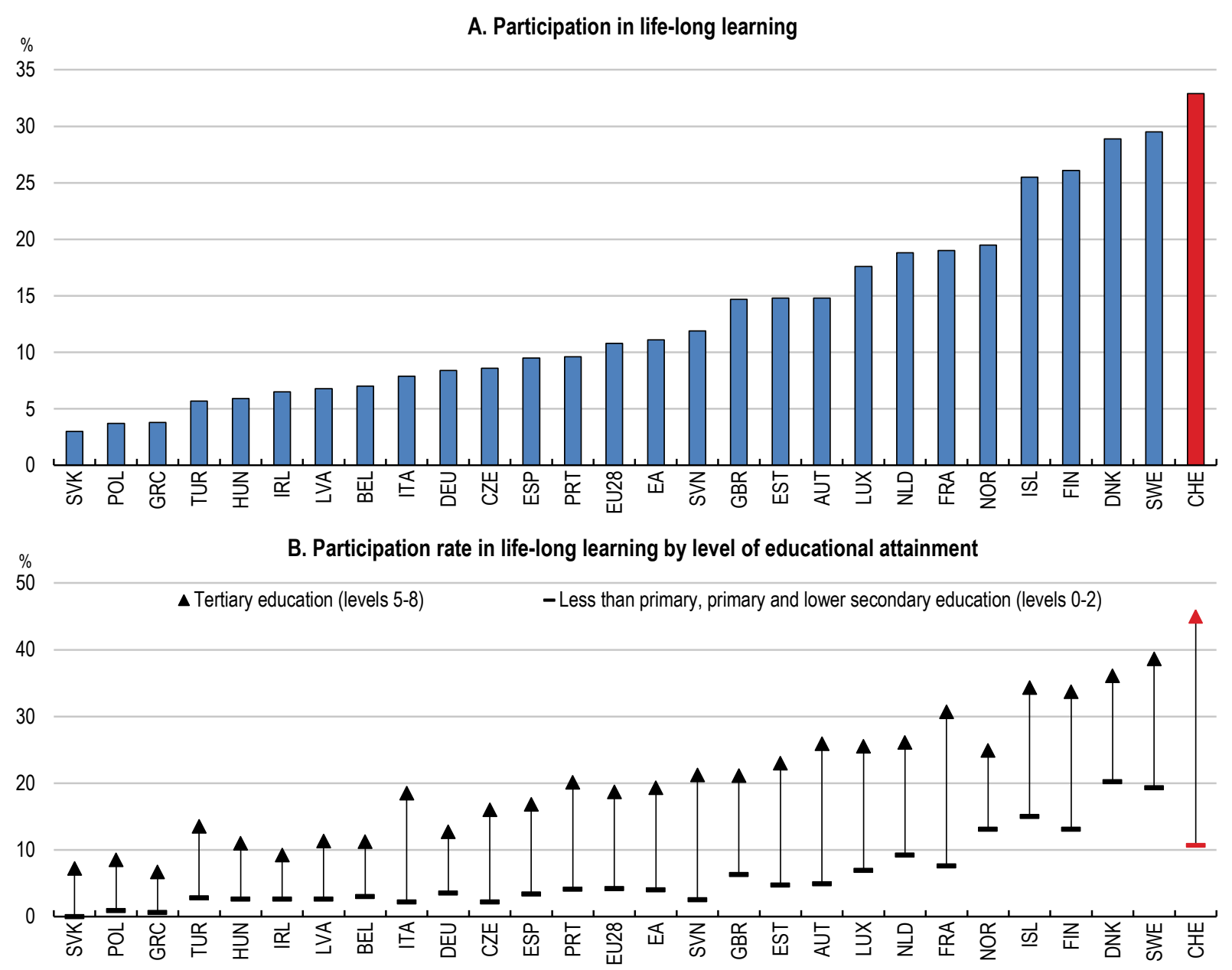

Source: Eurostat, Labour Force Survey 2016.

CET will become increasingly important as rising longevity means longer working lives and digitalisation causes changes in occupations and skills needed. As acknowledged by the Skilled Workers Initiative, CET will be necessary to improve the potential of the workforce (SECO, 2017). Because workers and firms may not fully internalise the need for further investment in human capital, subsidies may help incentivise take-up for groups with low participation rates. Canada and the Netherlands provide individual training accounts. The German government provides funds for retraining to workers without qualifications or who have spent at least four years in a job unrelated to their initial training (OECD, 2017f). In principle, financial incentives should be simple, able to adapt to new and emerging skill needs and complemented by information on skills and programmes and career guidance (ibid). Access to information and career guidance are important since workers may not realise that they can benefit from lifelong learning. In Austria, companies undergoing organisational change can access free counselling from the public employment service that includes the area of continuing vocational training. More flexible training such as distance learning or self-paced online courses could lower barriers to participation. 


\section{Equity in skills and education}

Maximising the employment of human resources in the economy means both encouraging participation and facilitating the accumulation of human capital for all segments of society, including women and migrants. In regard to both of these, Switzerland performs well relative to other countries (OECD, 2017g). Nonetheless, there are still gaps, implying more should be done.

\section{Gender}

As discussed in the 2013 OECD Economic Survey of Switzerland large gender-based economic disparities exist in Switzerland (OECD, 2013). While female participation in the labour force is very high by international standards, it is low compared to their male counterparts', and a very large proportion work only part-time. This, together with the unadjusted gender wage gap of $17 \%$ (relative to male median fulltime earnings), contributes to large differences in annual incomes (OECD, 2017g). In contrast, the earlier gender gap in education has now completely closed and even reversed, with Swiss women now accumulating more years of schooling than men. But in fields of study there remains a large differential. For example, in vocational education and training female participation in technical courses, such as engineering and computing, lags considerably, while in nursing the gap goes dramatically the other way (Figure 16). This heterogeneous pattern also occurs in courses of study at universities (OECD, 2013). It may also relate to the differences in attitudes and skills that develop early in the education system, as shown by the gender gaps in PISA scores for reading, maths and science (see Table 3 above).

Some researchers have suggested that a possible explanation for this gender-segmented allocation of students across fields of study may be found in the system of streaming at upper-secondary level. The Swiss post-compulsory education system is split between VET, capturing two thirds of students, and gymnasiums and specialised upper secondary schools providing general academic education for the remaining third. The split in education streams at age 15 requires students to make career choices early on. Statistical analysis (Imdorf et al., 2014) has shown that cantons with proportionally more gymnasiums have a lower degree of gender-typical allocation of men and women across fields of study. There can be several reasons for that. First, more academically oriented education systems offer more opportunities for students to change career paths according to preferences and abilities. By contrast, the variety of differentiated education options in the VET system may favour gender-typical choices at an age when gender plays an important role in shaping individual identity. Second, the academic track allows students to gain more maturity before making career choices.

Figure 16. Students in vocational education and training

Training sectors and gender, 2015/16 1

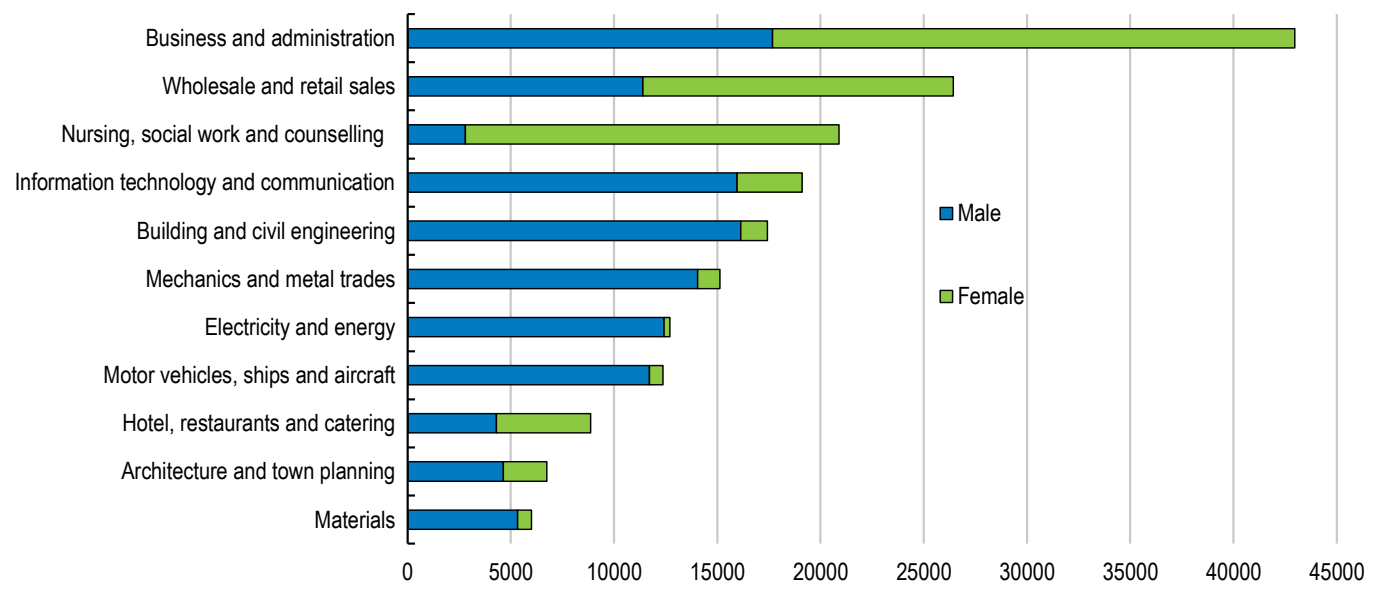

1. The training sectors not shown represent $17 \%$ of the students.

Source: Federal Statistical Office. 


\section{ECO/WKP(2017)76}

The fact that people think or behave differently from one another is rooted in individual differences in brain anatomy and connectivity, which develop later in life (Mueller et al., 2013). This maturity allows them to be less influenced by their friends and family, who may suggest gender-typical careers, and more by their personal interests or comparative advantages. Alternatively, the reason that girls are not rushing into scientific careers, or boys into care-based professions, may simply reflect individual preferences. Cross-country evidence collected for the 2012 OECD Gender Initiative points to a role for individual characteristics, family background and socio-economic background in determining post-secondary subject choices (OECD, 2012b). Mentors and positive atypical role models in the family, the educational system and professional life can help men and women choose gender-atypical careers, inducing others to follow suit.

Schools can help counter gender-based stereotypes by providing more information about potential careers (OECD, 2016b). Students are currently required to see a career counsellor once in their final year of lower secondary school, but this service could be expanded further. Employer talks have been found to be a cost-effective way of helping students better understand careers (Kashefpakdel and Percy, 2016). These could also be used to erode gender stereotypes. Reducing them may also help alleviate shortages in STEM and health-care professions.

\section{Migrants}

Switzerland has one of the OECD's largest immigrant population shares, and the country has long relied on foreign labour and skills to fill vacancies in the labour market. Over 2005-15, most migrants came from Germany, Portugal, France and Italy, which are all covered by the EU agreement on the free movement of people. Migrants from the former Yugoslavia are another important group in the population. Overall, labour market outcomes for the children of immigrants are highly favourable in international comparison. This is partly attributable to good overall labour market conditions and other factors such as the strong role of apprenticeship training, which seems to be a particularly beneficial school-to-work transition mechanism for such children (Liebig et al., 2012). However, there is strong evidence that Switzerland is not getting the best out of its population with a migrant background.

Migrant youth significantly underperform native-born youngsters in Switzerland. This pattern has been observed over all recent iterations of the PISA survey suggesting that any oversampling issues in the latest iteration of PISA in Switzerland do not affect this particular result. For instance, in science not only migrant youths but also those born to migrant parents underperformed youngsters with native-born parents by around $12 \%$. Overall, unlike other OECD countries with substantial immigrant shares such as Australia and Canada, in Switzerland the gap relative to students with native-born parents was equivalent for both foreign-born students and those who are born to immigrant parents, suggesting that lower performance seems to persist across generations of migrant families.

OECD research suggests that across countries, and despite improvements, having an immigration background is related to lower academic performance, which may have long-lasting consequences for individuals as they leave school and enter post-secondary education, training or the labour market (OECD, 2012a and 2015b). At the same time, empirical evidence shows that almost three-quarters of the performance at school of children with a migrant background is accounted for by socio-economic determinants, rather than their immigrant status per se (Cattaneo and Wolter, 2015). The government should therefore boost assistance aimed directly at socio-economically disadvantaged families. It should also encourage enrolment of children from families with an immigrant background in early childhood education and care, including with additional spending, as recommended in the 2015 Economic Survey of Switzerland. These families may be relatively less aware of the benefits of early childhood education. Conditional cash transfers could be used to encourage participation and could be trialled as a pilot programme in the first instance. 
The problem of underperforming native-born children of immigrants, noted in the 2009 Economic Survey of Switzerland (OECD, 2009), starts early. The failure to acquire a national language at an early age is a major impediment to success at education. A survey of parents conducted in Basel and its environs showed that children with an immigrant background have the least opportunity to access facilities provided outside the family, thereby hampering their ability to master an official language early on (SKBF, 2014).

The solution to underperformance of youths of immigrant background had been to direct them into "special education programmes". Children from an immigrant background were vastly overrepresented there: while around a quarter of all students in the compulsory system (up to age 15) are of migrant origin, they comprised almost half of all students in such programmes. However, even after two years in these and other special beginners' classes, most children of immigrant background were still not deemed capable of integrating into normal school classes due to a lower-than-average level of cognitive development and knowledge of the official language (Field et al., 2007). These special education programmes are used in a more focussed way now.

There is considerable clustering of students with immigrant backgrounds across schools. Around $60 \%$ of students with an immigrant background are in schools where at least half of the students have an immigrant background. However, while this may seem high, this degree of concentration is below the OECD average and lower than in comparable countries such as Sweden, Denmark and Canada, despite the especially high share of such students in Switzerland (OECD, 2015c). However, in Switzerland the clustering of students of migrant background is particularly deleterious in terms of outcomes. For instance, the difference in PISA science scores of students in schools with high and low concentrations of these students is particularly large in Switzerland (Figure 17).

Figure 17. Difference in PISA science score levels between students in schools with high and low concentrations of students with an immigrant background 1 , 2015

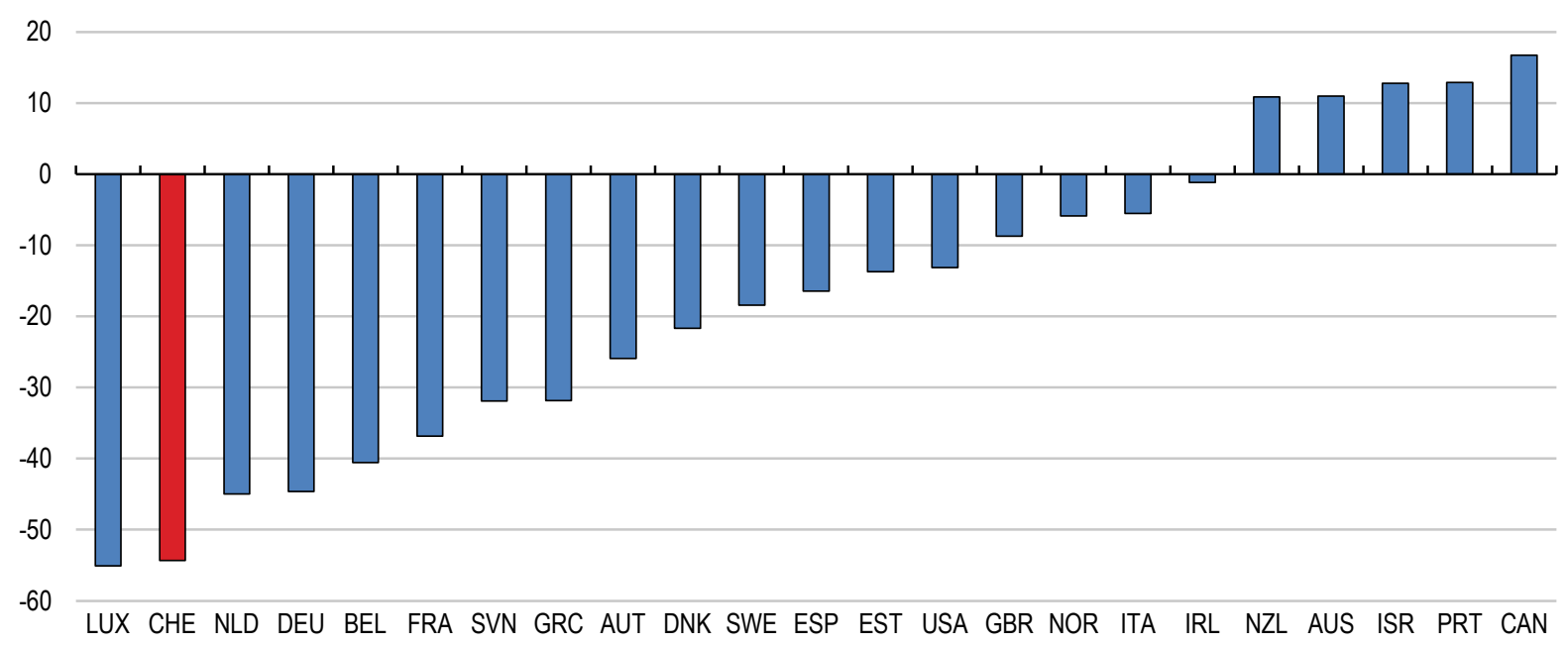

1. Students with an immigrant background are those who are foreign-born or have foreign-born parents. Schools with a low (high) concentration of students with an immigrant background are those schools in the bottom (top) half of the concentration distribution.

Source: OECD, PISA 2015 database.

Increased education spending on children with immigrant backgrounds promises above-average returns. In 2006 the Swiss Confederation and the cantons set an objective that $95 \%$ of all 25 year-olds hold 
an upper-secondary qualification. In the past 20 years that rate has fluctuated between 90 and $92 \%$ (SKBF, 2014). That goal has now been reached for the Swiss born, but outcomes are still far from the target for those born abroad (Wolter et al., 2014). However, some progress has been made. The PISA reading performance differential between young people with and without an immigrant background fell from 86 to 48 points between 2000 and 2009. In mathematics it also fell, from 76 to 63 points between 2003 and 2012. But roughly three-quarters of the narrowing, which primarily concerned migrant students, that is young people who were not born in Switzerland, can be ascribed to an increase in immigration from countries such as France and Germany, whose languages overlap with Switzerland's (Cattaneo and Wolter, 2015). Given sampling issues in the 2015 PISA iteration, it is hard to gauge the extent of recent changes.

Moreover, completing university has been shown to increase the earnings of men in Switzerland with disadvantaged family backgrounds, including from migrant backgrounds, even more than for those from more favoured backgrounds (Perini, 2014). The boost to employment rates is smaller, however (OECD/European Union, 2015). If increased pre-primary spending helps to increase the probability that these children get to university level, the net return would be even higher.

Another contributing factor to weaker performance by children with an immigrant background is the lack of diversity among teachers. A quarter of the Swiss population was born outside of the country, but foreign-born students represent only about $8 \%$ of those planning to teach at compulsory education level. A lack of linguistic and cultural diversity among the teaching profession can be problematic, in Switzerland as in other OECD countries, and a higher share of teachers from migrant families would help the integration of students from similar backgrounds. Specific measures such as those being implemented in Germany by the MigraMENTOR project could be fruitfully developed in Switzerland, making a teaching career more attractive to foreign students in particular.

\section{Tracking and equity}

In most cantons there is stratification by ability in lower secondary school before separating into vocational and academic schools at upper secondary school. The 2015 PISA results show that $29 \%$ of Swiss students were in schools where all classes are grouped by ability, which was the third-highest in the OECD. Grouping classes by ability appears to be becoming more common across countries, but PISA data caution that it does not improve the shares of low and top performers in an education system and that it can raise inequality (OECD, 2016e and 2012c; Causa and Johansson, 2010; Field et al., 2007). The risk is that students remain in one stream, and initially low-performing students will proceed to the vocational stream in upper secondary school as a matter of course, rather than the academic stream that is a pathway to a university education.

Previous OECD Economic Surveys and other OECD work have long argued in favour of a more comprehensive system of upper secondary education, not only in the case of Switzerland but also in other countries with similar systems, and that, if it is to exist, tracking should take place at an older age, although this may be difficult due to the link to the apprenticeship system. In recent years the rigidity of this system - that is the lack of permeability between the tracks - was alleviated through the introduction of the professional baccalaureate and universities of applied sciences that are open to vocational-stream students. Passerelles (pathways) were created that allow students to transition from the vocational stream to the traditional universities. However, the passerelles are still little-used, as they are expensive in terms of lost time and opportunity costs. Increasing the academic content in the early years of the two systems (and vice versa) may improve permeability and therefore flexibility and equity in the system overall.

One of the principle objections to early tracking is that it re-enforces intergenerational immobility in terms of educational achievement, educational paths and later economic outcomes. Empirical studies suggest that there is a positive association between enrolment in vocational education and training and the 
influence of parental background on offspring secondary achievement (Falcon, 2013; Jann and Seiler, 2013; Felouzis and Charmillot, 2013). The influence of parental background on offspring performance at secondary school tends to be lower in countries where tracking takes place at a later stage and/or in "comprehensive" systems where ability grouping within schools occurs to a lesser extent (Causa and Johansson, 2010). Bauer and Riphahn (2005) used the variation in age at tracking across cantons and found that early tracking reinforces the relative advantage of children of highly educated parents over those of parents with low levels of education (tracking happened at an earlier age at that time, but the principle still undoubtedly holds). Furthermore, early tracking appears to exacerbate achievement differences associated with the school's socio-economic mix without increasing overall performance (Causa and Johansson, 2010).

Research also shows considerable influence of gender, cultural and family background on the assigned type of track (Kronig, 2007). Finally, research by Pekkarinena et al. (2009), which exploits the fact that the move from tracking to a comprehensive system in Finland was implemented gradually across the country's municipalities during a six-year period, indicates that the reform reduced the intergenerational income elasticity from 0.30 to 0.23 . Tracking is also adding to the length of time taken to complete schooling via use of "transition years" between lower and upper secondary school. Jaik and Wolter (2016) show that "locus of control" - believing that outcomes depend on one's actions rather than external factors - is negatively related to delaying upper secondary school. Parental education and immigrant status is also linked to the decision to delay entering upper secondary school. This suggests that within the current system greater career guidance may be needed. But it also confirms that tracking may be taking place at an age at which students are ill-prepared to make important decisions. 
Recommendations to make education and skills training more responsive

(Key recommendations in bold)

\section{Increasing the responsiveness of the system to changing demands}

- Collect more detailed data on skills to facilitate adjustments to education in response to changing labour market needs. Commit to participating in the next rounds of PIAAC.

- Improve the availability of longitudinal or cohort data within the Swiss education system in order to better fine-tune the system in response to rapid changes in the structure of the economy.

- Undertake a review of the mix of education and skills training, given the high vacancy rates in the high-skill economic sectors.

- Increase the effectiveness of pathways between vocational and general streams by increasing the academic component of the vocational curriculum and vice versa.

- $\quad$ Strengthen linkages between the vocational education and training system and employer associations in school-based vocational training. Reduce delays in curriculum changes in the dual apprenticeship training system.

- Encourage small firms to participate more in apprenticeships by promoting sharing of apprenticeship places between firms and training centres that undertake part of the training.

- Complement the existing framework with a mechanism that helps players in education and training to make better forecasts and to anticipate shifts in the demand for skills.

- Strengthen linkages between higher education institutions and employers, including through closer cooperation in course design and facilitating linkages between students and employers.

- Use subsidies to encourage participation in continuing education and training for groups with low participation rates.

- Reduce fragmentation among jurisdictions and government departments responsible for continuing education and training and accelerate data collection.

\section{Ensuring equity in education and training}

- Ensure that lower secondary school students are assessed so that they can move between ability-based classes.

- Increase efforts to promote a better gender balance across occupations, and reduce gender stereotyping, including through increased career guidance and employer talks in lower secondary school.

- Encourage take-up of early childhood education for those from poorer socio-economic backgrounds, including immigrant backgrounds, for example by trialling means-tested conditional cash transfers. 


\section{REFERENCES}

Aghion, P. and P. Howitt (2009), The Economics of Growth, MIT Press, Cambridge, Massachusetts.

Arntz, M., T. Gregory and U. Zierahn (2016), "The Risk of Automation for Jobs in OECD Countries: A Comparative Analysis", OECD Social, Employment and Migration Working Papers, No. 189, OECD Publishing, Paris, http://dx.doi.org/10.1787/5jlz9h56dvq7-en

Basten, C. and M. Siegenthaler (2013), "Do Immigrants Take or Create Residents' Jobs?, QuasiExperimental Evidence from Switzerland”, KOF Working Papers, No. 335, Zurich.

Bauer, P. and R. Riphahn (2005), "Timing of School Tracking as a Determinant of Intergenerational Transmission of Education”, Economics Letters, Vol. 91, pp. 90-97.

Beerli, A. and G. Peri (2015), "The Labour Market Effects of Opening the Border: New Evidence from Switzerland", NBER Working Papers, No. 21319.

Berger, T. and C. Frey (2016), "Structural Transformation in the OECD: Digitalisation, Deindustrialisation and the Future of Work", OECD Social, Employment and Migration Working Papers, No. 193, OECD Publishing, Paris, http://dx.doi.org/10.1787/5jlr068802f7-en

Campbell, D. (2006), “What is Education's Impact on Civic and Social Engagement?", in R. Desjardins and T. Schuller (eds.), Measuring the Effects of Education on Health and Civic Engagement: Proceedings of the Copenhagen Symposium, OECD/CERI, OECD Publishing, Paris, pp. 25-126.

Cattaneo, M. A. and S. C. Wolter (2015), "Better Migrants, Better PISA Results: Findings from a Natural Experiment", IZA Journal of Migration, Vol. 4, No. 18.

Causa, O. and Å. Johansson (2010), "Intergenerational Social Mobility in OECD Countries", OECD Journal: Economic Studies, Volume 2010, OECD Publishing, Paris, http://dx.doi.org/10.1787/eco_studies-2010-5km33scz5rji

CIPD (2015), "Over-qualification and Skills Mismatch in the Graduate Labour Market”, Policy Report, August 2015.

Deloitte (2015), Man and Machine: Robots on the Rise?, Deloitte, Switzerland.

Economiesuisse (2017), "Engineers in Switzerland: State of Play", economiesuisse dossier politique, No 5.

Ecoplan (2017), "Formation Professionnelle 2030: Analyse SWOT", http://berufsbildung2030.ch/wsp/fr/analyse-swot/

ETLA (2014), "Computerisation Threatens One-third of Finnish Employment", The Research Institute of the Finnish Economy (ETLA), Brief 22, 13 January. 
Falcon, J. (2013), "Social mobility in 20th Century Switzerland”, Doctoral Thesis, Faculty of Social Sciences and Politics, University of Lausanne.

Felouzis, G. and S. Charmillot (2013), "School Tracking and Educational Inequality: A Comparison of 12 Education Systems in Switzerland", Comparative Education, Vol. 49, No. 2.

Field, S., M. Kuczera and B. Pont (2007), No More Failures: Ten Steps to Equity in Education, OECD Publishing, Paris, http://dx.doi.org/10.1787/9789264032606-en

Forster, A.G., T. Bol and H.G. van de Werfhorst (2016), "Vocational Education and Employment over the Life Cycle", Sociological Science, Vol. 3, pp. 473-94.

Frey, C. and M. Osborne (2013), "The Future of Employment: How Susceptible are Jobs to Computerisation?”, Oxford Martin School Working Paper.

Frey, C. and M. Osborne (2014), “UK Jobs at Risk?” in: Agiletown: the relentless march of technology and London's response, Deloitte.

FSO (2015), People in Education, Federal Statistics Office, Neuchâtel.

Geel, R. and U. Backes-Gellner (2011), "Career Entry and Success After Tertiary Vocation al Education", Leading House Working Papers, No. 52, The Swiss Leading House on Economics of Education, Firm Behaviour and Training Policies.

Gerfin, M. and B. Kaiser (2010), "The Effects of Immigration on Wages: An Application of the Structural Skill-cell Approach", Revue Suisse d'économie politique et de statistique, Vol. 146, No. 4, pp. 70939.

Hampf, F. and L. Woßmann (2016), "Vocational vs. General Education and Employment over the LifeCycle: New Evidence from PIAAC", IZA Discussion Papers, No. 10298.

Hanushek, E.A., G. Schwerdt, L. Wößmann and L. Zhang (2016), "General Education, Vocational Education, and Labor-Market Outcomes over the Life-Cycle", Journal of Human Resources, Vol. 52, No. 1, pp.48-87.

Hanushek, E. and L. Wößmann (2008), "The Role of Cognitive Skills in Economic Development”, Journal of Economic Literature, Vol. 46, No. 3, pp. 607-68, September.

Hanushek, E. and L. Wößmann (2011), "How Much do Educational Outcomes Matter in OECD Countries?”, Economic Policy, Vol. 26, No. 67, pp. 427-91.

Hoeckel, K., S. Field and W. Grubb (2009), Learning for Jobs: OECD Reviews of Vocational Education and Training: Switzerland, OECD Publishing, Paris, http://dx.doi.org/10.1787/9789264113985-en

Imdorf, C., S. Sacchi, K. Wohlgemuth, S. Cortesi and A. Schoch (2014), "How Cantonal Education Systems in Switzerland Promote Gender-Typical School-to-Work Transitions", Journal of Sociology, Vol. 40, No. 2, pp. 175-96.

Jaik, K. and S. C. Wolter (2016), "Lost in Transition: The Influence of Locus of Control on Delaying Educational Decisions", Swiss Leading House Working Paper, No. 118. 
Jann, B. and S. Seiler (2013), "Intergenerational Mobility in Switzerland: A Comparison of Methodological Approaches", unpublished, University of Lausanne.

Kashefpakdel, E.T. and C. Percy (2016), "Career Education that Works: an Economic Analysis Using the British Cohort Study", Journal of Education and Work, http://dx.doi.org/10.1080/13639080.2016.1177636.

Kronig, W. (2007), Die systematische Zufälligkeit des Bildungserfolgs. Theoretische Erklärungen und empirische Unter suchungen zur Lernentwicklung und zur Leistungsbewertung in unterschiedlichen Schulklassen, Haupt, Bern.

Krueger, A.B. and M. Lindahl (2001), "Education for Growth: Why and for Whom?," Journal of Economic Literature, Vol. 39, No. 4, pp. 1101-36.

Kuczera, M. (2017), "Striking the Right Balance: Costs and Benefits of Apprenticeship", OECD Education Working Papers, No. 153, OECD Publishing, Paris, http://dx.doi.org/10.1787/995fff01-en

Liebig, T., S. Kohls and K. Krause (2012), "The Labour Market Integration of Immigrants and their Children in Switzerland", OECD Social, Employment and Migration Working Papers, No. 128, OECD Publishing, Paris, http://dx.doi.org/10.1787/9789264167537-9-en

Meyer, T. (2009), "Can 'Vocationalisation' of Education Go Too Far? The Case of Switzerland”, European Journal of Vocational Training, No. 46, 2009/1.

Muehlemann, S. (2014), “Training Participation of Internationalized Firms: Establishment-level Evidence for Switzerland", Empirical Research in Vocational Education and Training, Vol. 6, No. 5.

Mueller, S., W. Danhong, M. Fox, B. Yeo, J. Sepulcre, M. Sabuncu, R. Shafee, J. Lu and H. Liu (2013), "Individual Variability in Functional Connectivity Architecture of the Human Brain", Neuron, Vol. 77, No. 3.

OECD (2009), Economic Survey of Switzerland 2009, OECD Publishing, Paris, http://dx.doi.org/10.1787/eco_surveys-che-2009-en

OECD (2010a), Improving Health and Social Cohesion through Education, Educational Research and Innovation, OECD Publishing, Paris, http://dx.doi.org/10.1787/9789264086319-en

OECD (2010b), Learning for Jobs, Synthesis Report of the OECD Reviews of Vocational Education and Training, OECD Publishing, Paris, http://dx.doi.org/10.1787/9789264087460-en

OECD (2012a), Better Skills, Better Jobs, Better Lives: A Strategic Approach to Skills Policies, OECD Publishing, Paris, http://dx.doi.org/10.1787/9789264177338-en

OECD (2012b), Closing the Gender Gap: Act Now, OECD Publishing, Paris, http://dx.doi.org/10.1787/9789264179370-en

OECD (2012c), Equity and Quality in Education: Supporting Disadvantaged Students and Schools, OECD Publishing, Paris, http://dx.doi.org/10.1787/9789264130852-en

OECD (2013), Economic Survey of Switzerland 2013, OECD Publishing, Paris, http://dx.doi.org/10.1787/eco_surveys-che-2013-en 
OECD (2015a), Economic Survey of Switzerland 2015, OECD Publishing, Paris, http://dx.doi.org/10.1787/eco_surveys-che-2015-en

OECD (2015b), Education at a Glance 2015, OECD Publishing, Paris, http://dx.doi.org/10.1787/eag-2015en

OECD (2015c), Immigrant Students at School: Easing the Journey towards Integration, OECD Publishing, Paris, http://dx.doi.org/10.1787/9789264249509-en

OECD (2016a), Education at a Glance 2016, OECD Publishing, Paris, http://dx.doi.org/10.1787/eag-2016en

OECD (2016b), PISA 2015 Results (Volume I): Excellence and Equity in Education, OECD Publishing, Paris, http://dx.doi.org/10.1787/9789264266490-en

OECD (2016c), Getting Skills Right: Assessing and Anticipating Changing Skill Needs, OECD Publishing, Paris. http://dx.doi.org/10.1787/9789264252073-en

OECD (2016d), "Skills for a Digital World”, Policy Brief on the Future of Work, OECD Publishing, Paris.

OECD (2016e), Low-Performing Students: Why They Fall Behind and How to Help Them Succeed, PISA, OECD Publishing, Paris, http://dx.doi.org/10.1787/9789264250246-en

OECD (2017a), Education at a Glance 2017, OECD Publishing, Paris, http://dx.doi.org/10.1787/eag-2017$\underline{\text { en }}$

OECD (2017b), Getting Skills Right: Skills for Jobs Indicators, OECD Publishing, Paris, http://dx.doi.org/10.1787/9789264277878-en

OECD (2017c), Going Digital: Making the Transformation Work for Growth and Well-being, Report for the Meeting of the OECD Council at Ministerial Level, Paris, www.oecd.org/mcm/documents/CMIN-2017-4\%20EN.pdf

OECD (2017d), OECD Skills Outlook 2017: Skills and Global Value Chains, OECD Publishing, Paris. http://dx.doi.org/10.1787/9789264273351-en

OECD (2017e), "Inclusive Labour Markets in the Digital Era”, in OECD Economic Surveys: Austria 2017, OECD Publishing, Paris, http://dx.doi.org/10.1787/eco surveys-aut-2017-6-en

OECD (2017f), Financial Incentives for Steering Education and Training, Getting Skills Right, OECD Publishing, Paris, http://dx.doi.org/10.1787/9789264272415-en

OECD (2017g), OECD Employment Outlook 2017, OECD Publishing, Paris, http://dx.doi.org/10.1787/empl outlook-2017-en

OECD/European Union (2015), Indicators of Immigrant Integration 2015: Settling In, OECD Publishing, Paris, http://dx.doi.org/10.1787/9789264234024-en

Oesch, D. and J.R. Menés (2010), "Upgrading or Polarization? Occupational Change in Britain, Germany, Spain and Switzerland, 1990-2008”, Socio-Economic Review, Vol. 9, pp. 503-31. 
ECO/WKP(2017)76

Ollivaud, P. (2017), "Boosting productivity in Switzerland", OECD Economics Department Working Papers, forthcoming, OECD Publishing, Paris.

Perini, L. (2014), "Who Benefits Most from University Education in Switzerland?" Swiss Journal of Economics and Statistics, Vol. 150, No. 2, pp. 119-59.

SECO (2017), "Pénurie de main-d'oeuvre qualifiée en Suisse : Système d'indicateurs pour évaluer la demande en personnel qualifié", State Secretariat for Economic Affairs, Bern.

SERI (2016), Vocational and Professional Education and Training in Switzerland: Facts and Figures 2016, State Secretariat for Education, Research and Innovation, Bern

SERI (2017), “VPET Partner Conference 2017”, SBFI News SERI, May 2017, State Secretariat for Education, Research and Innovation, Bern.

SKBF (2014), Swiss Education Report | 2014, SKBF/CSRE (Swiss Coordination Centre for Research in Education), Aarau.

Swiss Confederation (2017), Retour Sur Quinze Années De Libre Circulation Des Personnes, Swiss Confederation, Bern.

Vandenbussche, J., P. Aghion, and C. Meghir (2006), "Growth, Distance to Frontier and Composition of Human Capital", Journal of Economic Growth, Vol. 11, No. 2, June, pp. 97-127.

Windisch, H. (2015), “Adults with Low Literacy and Numeracy Skills: A Literature Review on Policy Intervention”, OECD Education Working Papers, No. 123, OECD Publishing, Paris, http://dx.doi.org/10.1787/5jrxnjdd3r5k-en

Wolter, S., A. Diem and D. Messer (2014), "Drop-outs from Swiss Universities: an Empirical Analysis of Data on All Students between 1975 and 2008", European Journal of Education, Vol. 49, Issue 4, pp. 471-83. 